University of Nebraska - Lincoln

DigitalCommons@University of Nebraska - Lincoln

Publications from USDA-ARS / UNL Faculty

U.S. Department of Agriculture: Agricultural

Research Service, Lincoln, Nebraska

2011

\title{
Climate Impacts on Agriculture: Implications for Crop Production
}

J. L. Hatfield

USDA-ARS, jerry.hatfield@ars.usda.gov

K. J. Boote

University of Florida, kjboote@ufl.edu

B. A. Kimball

USDA-ARS, bruce.kimball@ars.usda.gov

L. H. Ziska

USDA Crop Systems and Global Change Laboratory, I.ziska@ars.usda.gov

R. C. Izaurralde

University of Maryland - College Park, cizaurra@umd.edu

See next page for additional authors

Follow this and additional works at: https://digitalcommons.unl.edu/usdaarsfacpub

Hatfield, J. L.; Boote, K. J.; Kimball, B. A.; Ziska, L. H.; Izaurralde, R. C.; Ort, D. R; Thomson, A. M.; and Wolfe, D., "Climate Impacts on Agriculture: Implications for Crop Production" (2011). Publications from USDA-ARS / UNL Faculty. 1350.

https://digitalcommons.unl.edu/usdaarsfacpub/1350

This Article is brought to you for free and open access by the U.S. Department of Agriculture: Agricultural Research Service, Lincoln, Nebraska at DigitalCommons@University of Nebraska - Lincoln. It has been accepted for inclusion in Publications from USDA-ARS / UNL Faculty by an authorized administrator of DigitalCommons@University of Nebraska - Lincoln. 


\section{Authors}

J. L. Hatfield; K. J. Boote; B. A. Kimball; L. H. Ziska; R. C. Izaurralde; D. R, Ort; A. M. Thomson; and D. Wolfe 


\title{
Climate Impacts on Agriculture: Implications for Crop Production
}

(1)

\author{
J. L. Hatfield,* K. J. Boote, B. A. Kimball, L. H. Ziska, R. C. Izaurralde, \\ D. Ort, A. M. Thomson, and D. Wolfe
}

\begin{abstract}
Changes in temperature, $\mathrm{CO}_{2}$, and precipitation under the scenarios of climate change for the next $30 \mathrm{yr}$ present a challenge to crop production. This review focuses on the impact of temperature, $\mathrm{CO}_{2}$, and ozone on agronomic crops and the implications for crop production. Understanding these implications for agricultural crops is critical for developing cropping systems resilient to stresses induced by climate change. There is variation among crops in their response to $\mathrm{CO}_{2}$, temperature, and precipitation changes and, with the regional differences in predicted climate, a situation is created in which the responses will be further complicated. For example, the temperature effects on soybean [Glycine max (L.) Merr.] could potentially cause yield reductions of $2.4 \%$ in the South but an increase of $1.7 \%$ in the Midwest. The frequency of years when temperatures exceed thresholds for damage during critical growth stages is likely to increase for some crops and regions. The increase in $\mathrm{CO}_{2}$ contributes significantly to enhanced plant growth and improved water use efficiency (WUE); however, there may be a downscaling of these positive impacts due to higher temperatures plants will experience during their growth cycle. A challenge is to understand the interactions of the changing climatic parameters because of the interactions among temperature, $\mathrm{CO}_{2}$, and precipitation on plant growth and development and also on the biotic stresses of weeds, insects, and diseases. Agronomists will have to consider the variations in temperature and precipitation as part of the production system if they are to ensure the food security required by an ever increasing population.
\end{abstract}

$\mathrm{T}$ HERE IS MOUNTING evidence the current changes in climate across the Northern Hemisphere will continue into the future and affect temperature, precipitation, and atmospheric $\mathrm{CO}_{2}$ concentration. Karl et al. (2009) presented an analysis of the recent changes in the climate of the United States and projected changes over the next century. Temperature and precipitation patterns across the United States for the next $30 \mathrm{yr}$ show a warming trend of 1.5 to $2^{\circ} \mathrm{C}$ and a slight increase in precipitation over most of the country (e.g., Tebaldi et al., 2006; Karl et al., 2009). They projected an increase in the number of days when the temperature will be higher than the climatic normals by $5^{\circ} \mathrm{C}$ (heat-waves), which will impact agricultural systems. These authors also project an increase in warm nights, defined as occurring when the minimum temperature is above the 90th percentile of the climatological distribution for the day (Tebaldi et al., 2006; Karl et al., 2009). Coupled with these changes is the decrease in a number

\footnotetext{
J.L. Hatfield, Laboratory Director, National Laboratory for Agriculture and the Environment, Ames, IA 50011; K.J. Boote, Agronomy Dep., Univ. of Florida, Gainesville, FL 32611; B.A. Kimball, USDA-ARS, U.S. Arid-Land Agricultural Research Center, Maricopa, AZ 85138; L.H. Ziska, USDA Crop Systems and Global Change Lab., Beltsville, MD 20705; R.C. Izaurralde, Joint Global Change Research Institute, Pacific Northwest National Lab., Univ. of Maryland, College Park, MD 20740; D.R. Ort, USDA/ARS, Photosynthesis Research Unit, Univ. of Illinois, Urbana, IL 61801; A. M. Thomson, Joint Global Change Research Institute, Pacific Northwest National Lab., Univ. of Maryland, College Park, MD 20740; David W. Wolfe, Dep. of Horticulture, Cornell Univ., Ithaca, NY 14853. Received 9 July 2010. ${ }^{*}$ Corresponding author (jerry.hatfield@ars.usda.gov).

Published in Agron. J. 103:351-370 (2011)

Published online 30 Dec 2010 doi:10.2134/agronj2010.0303

Copyright (c) 2011 by the American Society of Agronomy, 5585 Guilford Road, Madison, WI 53711. All rights reserved. No part of this periodical may be reproduced or transmitted in any form or by any means, electronic or mechanical, including photocopying, recording, or any information storage and retrieval system, without permission in writing from the publisher.
}

of frost days by $10 \%$ in the eastern half of the United States and an increase in the length of the growing season by more than $10 \mathrm{~d}$. Karl et al. (2009) showed that precipitation events would change in frequency and intensity with a projected increase in spring precipitation, particularly in the Northeast and Midwest United States, and a decline in the southwestern United States. The increase in extreme temperature events, warm nights, and more variable precipitation will impact agriculture and agricultural production. A trend for warmer winters will affect perennial crops and weeds, and also expand the potential habitable range of some insect and disease pests. Although there is uncertainty about the absolute magnitude of the changes over the next $50 \mathrm{yr}$, there is general agreement that $\mathrm{CO}_{2}$ levels will increase to near $450 \mu \mathrm{mol} \mathrm{mol}{ }^{-1}(\mathrm{ppm})$, temperatures will increase by 0.8 to $1.0^{\circ} \mathrm{C}$, and precipitation will become more variable as defined in the IPCC AR4 analysis (IPCC, 2007). Changes in temperature have already caused longer growing seasons and begun to impact phenological phases (Schwartz et al., 2006; Wolfe et al., 2005, Xiao et al., 2008; Karl et al., 2009).

An example of the potential of climate change impacts on agriculture is illustrated in a recent study by Ortiz et al. (2008) in which they assessed the potential impact on India wheat (Triticum aestivum L.) production if air temperature increased $0.8^{\circ} \mathrm{C}$ over the next $50 \mathrm{yr}$. Their analysis showed that as much as $51 \%$ of the area in India currently classified as high potential, irrigated, low rainfall mega-environment would be reclassified to a heat-stressed, irrigated, short-season production mega-environment. This area currently accounts for $15 \%$ of the world's wheat production and would undergo significant reduction in yield unless cultivars and management practices adapted to the projected climate regime (e.g., higher levels of heat and water

Abbreviations: ET, evapotranspiration ; FACE, free-air carbon dioxide enrichment; HI, harvest index; LAI, leaf area index; VPD, vapor pressure deficit; WUE, water use efficiency. 
stress) were developed. Without adaptation, the impacts on the production potential would drastically alter the ability of India to produce a sufficient food supply for its population.

Projected increases in temperatures for the entire United States will increase soil water evaporation and crop transpiration. This could lead to an increase in soil water deficits and economic losses unless mitigated by other factors, such as: a corresponding increase in precipitation; an increase in crop WUE (associated with $\mathrm{CO}_{2}$ effects on stomatal closure, see discussion below); reductions in leaf area or planting density; and farmer adaptations, for example, increasing use of supplemental irrigation. A recent climate analysis for the northeastern United States (Hayhoe et al., 2007) projected a significant increase in summer soil water deficits by mid-century even for this relatively humid region with little change in total annual precipitation. In the western United States, reduction in snow pack and earlier snow melt exacerbate the potential threat of drought for farmers because of the reduction in the reservoir of water available for irrigation (Lettenmaier et al., 2008). Similar results were reported by Wang (2005) after comparing 15 different models for the IPCC fourth assessment and concluded the increases in greenhouse gases will cause a worldwide increase in the occurrence of agricultural droughts. These models were consistent in their predictions of drier soil over the Southwest United States across all seasons. Across the Midwest, Mishra and Cherkauer (2010) found that droughts have actually decreased in the last half of the 20th century with the last significant widespread droughts in the 1930s. However, within this record, they found maize (Zea mays L.) and soybean yields to be correlated with meteorological drought and maximum daily temperature during the grain-filling period. Drought was found to be the major factor leading to yield variability of eight different crops over years for the Czech Republic (Hlavinka et al., 2009). Water availability will become a major determinant in crop yield (Rosenzweig et al., 2002) and the interaction with $\mathrm{CO}_{2}$ and temperature will have to be understood better to adapt cropping systems to climate change.

The prediction of an increase in the frequency of high-precipitation events (e.g., $>5 \mathrm{~cm}$ in $48 \mathrm{~h}$ ) may be of great concern in many parts of the United States equally as drought because of the inability of the soil to maintain infiltration rates high enough to absorb high-intensity rainfall events (Hayhoe et al., 2007). This trend is projected to apply for many regions (Lettenmaier et al., 2008). Excessive rainfall during the spring planting season could cause delays creating a risk for both productivity and profitability for agronomic crops (Rosenzweig et al., 2002) as well as high value horticultural crops such as melon (Cucumis melo), sweet corn (Zea mays L. var. rugosa), and tomato (Lycopersicon esculentum L.) for which premiums are often paid for early season production. Crop losses associated with anoxia, increases to susceptibility to root diseases, increases in soil compaction (due to use of heavy farm equipment on wet soils), and more runoff and leaching of nutrients and agricultural chemicals into ground-and surface-waters may occur as the result of excess soil water and field flooding during the early growing season. The shift in the rainfall distribution because of high precipitation events could increase the likelihood of water deficiencies at other times because of the changes in rainfall frequency (Hatfield and Prueger, 2004). Increases in heavy rainfall due to more intense storms and associated turbulence and wind gusts, increase the potential for lodging of crops. Delayed harvest or excessive rainfall during harvest time increases the potential for decreasing quality of many crops and potential for disease infestation on grains.

Solar radiation is a driving variable in crop production and there is a belief that as water vapor and cloud cover increase there will be a decrease in incoming solar radiation. Stanhill and Cohen (2001) referred to this as "global dimming" and found for the past $50 \mathrm{yr}$ a reduction of $2.7 \%$ per decade with the current totals now being reduced $20 \mathrm{~W} \mathrm{~m}^{-2}$. These changes would impact crop water balance and evapotranspiration of crops with less effect on crop productivity because of the presence of other factors limiting productivity (e.g., water, temperature). Even though the assumption is for solar radiation changes to have a minimal impact on crop productivity, this review points out the need for better understanding of the impact of this variable as part of the climate change scenario. There must be efforts to develop adaptive management strategies to cope with climate change along with mitigation strategies to reduce the impact of agricultural practices on the environment. As agronomists we need to be engaged in helping develop both adaptative management and mitigation strategies to ensure the future food, feed, fuel, and fiber supply for the world's population. Adams et al. (1990) stated that agricultural productivity is sensitive to climate change and that there are positive effects from climate change (i.e., increased $\mathrm{CO}_{2}$ ) and negative impacts (e.g., higher temperatures shortening grain-fill duration and increasing evapotranspiration rates). The uncertainty in the climate for the next decades and the potential impact on agricultural production were reviewed as part of the Climate Change Science Program (CCSP) under Synthesis and Assessment Product 4.3 (SAP4.3) and published as part of this report series (Hatfield et al., 2008). There is evidence that our climate is changing and that these changes in temperature, precipitation (both amount and frequency), $\mathrm{CO}_{2}$, and $\mathrm{O}_{3}$ will impact agriculture. The intent of this review is not to review the climate change literature but to evaluate the potential impacts of climate change on agricultural crops and to expand on some of the findings in the SAP4.3 report with focus on agronomic crops, to summarize the current state of knowledge, and to offer ideas as to where future efforts should be placed to reduce the potential negative impacts of climate change on agriculture and future food, feed, and fiber production.

\section{CARBON DIOXIDE IMPACTS ON CROPS}

Carbon dioxide levels in the atmosphere have increased steadily over the past $50 \mathrm{yr}$ and the expectation is for a continued increase over the next $30 \mathrm{yr}$. By conservative estimates, the current levels of about $387 \mu \mathrm{mol} \mathrm{mol}^{-1}$ will increase to nearly $450 \mu \mathrm{mol} \mathrm{mol}^{-1}$ by 2050 and in fact are increasing faster than expected (Karl et al., 2009). To quantify the effect of changes in $\mathrm{CO}_{2}$ concentrations, one must conduct plant growth and yield studies in systems where $\mathrm{CO}_{2}$ concentration can be maintained above the ambient levels. These have been done in a combination of enclosed chambers and free-air carbon dioxide enrichment (FACE) studies. Kimball (1983) summarized early studies on the effects of increases from 330 to $660 \mu \mathrm{mol} \mathrm{mol}^{-1}$. Subsequent implementation of FACE technology has enabled open-field studies and have increased the confidence in evaluating the effect of increasing $\mathrm{CO}_{2}$ concentrations on plant response (e.g., Kimball and Mauney, 1993; Kimball et al., 1995, 2002; Ainsworth and Long., 2005; Kimball, 2010). However, Long et al. (2006) recently showed yield responses 
Table I. Response of plant physiological variables to a doubling of $\mathrm{CO}_{2}$ concentrations from research studies.

\begin{tabular}{|c|c|c|c|c|c|}
\hline \multirow[t]{2}{*}{ Crop } & Leaf photosynthesis & \multirow[t]{2}{*}{ Total biomass } & Grain yield & Leaf stomatal conductance & \multirow[t]{2}{*}{ Canopy evapotranspiration } \\
\hline & & & $\%$ & ge & \\
\hline Maize & $3^{\dagger}$ & $4^{\dagger, \ddagger, \S, \boldsymbol{q}}$ & $4^{\dagger, \ddagger}$ & $-34^{\dagger}$ & \\
\hline Sorghum & $9^{\#, \dagger \dagger}$ & $3 \ddagger \ddagger$ & $0,8^{\#}$ & $-37+\dagger$ & $-13 \S \S$ \\
\hline Bean & 50शा & 30ाтा & 27ाা & & \\
\hline Cotton & $33^{\# \#,+\dagger \dagger}$ & $36^{\# \#, t+\dagger}$ & $44^{\# \#,+\dagger \dagger}$ & $-36^{\#,+\dagger \dagger \dagger}$ & $0 \S \S \S \S \S \S,-8 \neq \ddagger \ddagger$ \\
\hline Peanut & 27ाাा & 36 गा & उ०शा & & \\
\hline Rice & $36 \S \S \S$ & $30 \S \S \S$ & 30§§§, Пाтा & & $-10^{\# \# \#,+\dagger \dagger \dagger}$ \\
\hline Soybean & 35 拉 & 37 拉 & $34 \S \S \S \S \_38$ 㧊 & $-40 \neq \ddagger \neq \ddagger$ & -9ाभाтा, -12\#\#\#,t+十†† \\
\hline Wheat & 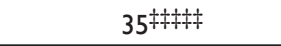 & $15-27 \S \S \S \S \S$ & 3। Іाтाभा & 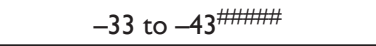 & 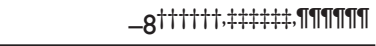 \\
\hline \multicolumn{2}{|c|}{ † Leakey et al. (2006). } & \multicolumn{2}{|c|}{ ††† Reddy et al. (1997). } & \multicolumn{2}{|c|}{ ††††† Bernacchi et al. (2007). } \\
\hline \multicolumn{2}{|c|}{$\ddagger$ King and Greer (1986). } & \multicolumn{2}{|c|}{ 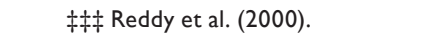 } & \multicolumn{2}{|c|}{ 抽† Long (1991). } \\
\hline \multicolumn{2}{|c|}{$\S$ Ziska and Bunce (1997). } & \multicolumn{2}{|c|}{$\S \S \S$ Horie et al. (2000). } & \multicolumn{2}{|c|}{$\S \S \S \S \S$ Lawlor and Mitchell (2000). } \\
\hline \multicolumn{2}{|c|}{ TI Maroco et al. (1999). } & \multicolumn{2}{|c|}{ শাा Baker and Allen (1993a). } & \multicolumn{2}{|c|}{ ণাाাा Amthor (200I). } \\
\hline \multicolumn{2}{|c|}{ \# Prasad et al. (2006a). } & \multicolumn{2}{|c|}{ \#\#\# Baker et al. (1989). } & \multicolumn{2}{|c|}{ \#\#\#\#\# Wall et al. (2006). } \\
\hline \multicolumn{2}{|c|}{$\dagger †$ Wall et al. (200l). } & \multicolumn{2}{|c|}{ †††† Yoshimoto et al. (2005). } & \multicolumn{2}{|c|}{ ††††††Andre and duCloux (1993). } \\
\hline \multicolumn{2}{|c|}{$\ddagger \ddagger O$ ttman et al. (200I). } & \multicolumn{2}{|c|}{ 拉 Ainsworth et al. (2002). } & \multicolumn{2}{|c|}{ 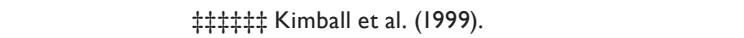 } \\
\hline \multicolumn{2}{|c|}{$\S \S$ Triggs et al. (2004). } & \multicolumn{2}{|c|}{$\S \S \S \S$ Allen and Boote (2000). } & \multicolumn{2}{|c|}{$\S \S \S \S \S \S$ Hunsaker et al. (1994). } \\
\hline \multicolumn{2}{|c|}{ ПТ Prasad et al. (2003). } & \multicolumn{2}{|c|}{ ளाাाা Allen et al. (2003). } & \multicolumn{2}{|c|}{ গাণাाা Hunsaker et al. $(1996,2000)$. } \\
\hline \multicolumn{2}{|c|}{ \#\# Reddy et al. (1995a). } & \#\#\#\# Jones & (1985). & & \\
\hline
\end{tabular}

of cereal grains from the FACE experiments (about 15\% with enrichment to $550 \mu \mathrm{mol} \mathrm{mol}^{-1}$ of $\mathrm{CO}_{2}$ ) were less than those from some previous chamber-based studies (about 30\% with enrichment to $660 \mu \mathrm{mol} \mathrm{mol}^{-1}$ ), which raised concern. However, when the variability of results from a larger population of available chamber studies was considered it appears that results from the several types of experiments are not inconsistent.

The effects of increasing $\mathrm{CO}_{2}$ concentrations on various crops are summarized in Table 1. Increases in plant growth vary among species. As expected the crops with the so-called $\mathrm{C}_{4}$ photosynthetic pathway, maize, and sorghum [Sorghum bicolor (L.) Moench], have smaller responses than the $\mathrm{C}_{3}$ crops. Cotton (Gossypium hirsutum L.) may be higher because it is a woody species. However, all show a positive response to $\mathrm{CO}_{2}$ increases. In general, doubling $\mathrm{CO}_{2}$ caused approximately a $30 \%$ increase in reproductive yield of $\mathrm{C}_{3}$ species and $<10 \%$ increase for $\mathrm{C}_{4}$ species. Many $\mathrm{C}_{3}$ weed species also show substantial growth benefits and resistance to herbicides at elevated $\mathrm{CO}_{2}$ (Ziska, 2003b; Ziska et al., 1999), a topic which is further expanded in a later section on Projection for Weeds.

Concerns have been raised about the findings from small chambers and even of FACE approaches to studying the impact of increasing $\mathrm{CO} 2$ on plant response. The primary concerns are the experiment duration, small sample sizes for plant measurements, and lack of variation in other influencing factors, e.g., temperature or precipitation or $\mathrm{N}$ fertility affecting plant growth. Plant response to changes in $\mathrm{CO} 2$ concentration are complex and depend upon the species, interactions with temperature, soil moisture, nutrient management, and magnitude of acclimation to these factors (Long, 1991; Wolfe et al., 1998). The projections for increasing variability in precipitation and potential drought and increasing temperature as additional climatic factors, of course, may offset the positive impacts of rising $\mathrm{CO} 2$ on plant growth.

\section{Crop Water Use Efficiency Interactions with Carbon Dioxide}

Crop water use (i.e., transpiration, $\mathrm{T}$ ) is determined by crop physiological and morphological characteristics (e.g., Kimball, 2007) and is often described by the Penman-Monteith equation
(Allen et al., 2005). The Penman-Monteith equation defines the mechanisms by which changes in temperature, $\mathrm{CO}_{2}$, and $\mathrm{O}_{3}$ directly affect water use (assuming $\mathrm{O}_{3}$ as well as $\mathrm{CO}_{2}$ affect stomatal resistance). Transpiration is affected through effects on crop growth and leaf area, changes in leaf stomatal aperture and conductance for water vapor loss, and vapor pressure gradient between the ambient air and substomatal cavity.

In the early stages of crop development, increases in leaf area are proportional to growth rate and transpiration increases as leaf area increases (Ritchie, 1972). As plants develop, there is an increase in mutual shading and interference among leaves within a plant canopy which causes plant transpiration to increase at a diminishing rate with increasing leaf area index (LAI) and asymptotically leveling at LAIs $>4 \mathrm{~m}^{2} \mathrm{~m}^{-2}$, progressively uncoupling transpiration from changes in LAI (Ritchie, 1972; Villalobos and Fereres, 1990; Sau et al., 2004). Doubling of atmospheric $\mathrm{CO}_{2}$ from present-day levels will increase average $\mathrm{C}_{3}$ species growth on the order of $30 \%$ under optimum conditions (e.g., Kimball, 1983, 2007, 2010; Kimball et al., 2002) with the expectation that an increase to $440 \mu \mathrm{mol} \mathrm{mol}^{-1}$ would increase $\mathrm{C}_{3}$ plant growth on the order of $10 \%$. Since $T$ is most tightly coupled to changes in growth when plants are small and less after canopy closure, the overall impact of changes in $\mathrm{CO}_{2}$ via $\mathrm{LAI}$ effect are expected to be small. Of greater importance is the duration of leaf area which will directly affect total seasonal crop water requirements. In determinate cereal crops that are adapted to today's temperature and growing-season length, increasing temperature will hasten plant maturity reducing leaf area duration with an overall reduction in total season water requirement. However, if alternative crops or perennial crops or varieties adapted to the higher temperatures and longer growing season are used, crop water requirements would likely increase. However, a direct effect of increasing atmospheric $\mathrm{CO}_{2}$ is to cause partial stomatal closure. The result decreases conductance for water vapor loss from leaves to the atmosphere. A summary of the information available from chamber-based studies on the effects of elevated $\mathrm{CO}_{2}$ on stomatal conductance have shown, on average, that doubling $\mathrm{CO}_{2}$ reduces stomatal conductance by nearly $34 \%$ (e.g., Kimball and Idso, 1983). Morison (1987) found an average reduction of about $40 \%$ for both $\mathrm{C}_{3}$ 
and $\mathrm{C}_{4}$ species. Wand et al. (1999), after a meta-analysis on wild $\mathrm{C}_{3}$ and $\mathrm{C}_{4}$ grass species, grown with no stresses, concluded that elevated $\mathrm{CO}_{2}$ reduced stomatal conductance by $39 \%$ in $\mathrm{C}_{3}$ and $29 \%$ in $\mathrm{C}_{4}$ species. In soybean, the reduction in conductance was about $40 \%$ for a doubling of $\mathrm{CO}_{2}$ (Ainsworth et al., 2002; Ainsworth and Rogers, 2007). Ainsworth and Long (2005) did not observe significant differences in stomatal conductance of two $\mathrm{C}_{3}$ and $\mathrm{C}_{4}$ species when they summarized results from free-air $\mathrm{CO}_{2}$ enrichment experiments where daytime $\mathrm{CO}_{2}$ concentrations were increased from present to 550 to $600 \mu \mathrm{mol} \mathrm{mol}^{-1}$. They found an average reduction in stomatal conductance of $20 \%$. Thus, increases in atmospheric $\mathrm{CO}_{2}$ concentration to nearly $450 \mu \mathrm{mol} \mathrm{mol}^{-1}$ as estimated (IPCC, 2007) by 2040 likely will cause reductions of approximately $10 \%$ in stomatal conductance. Such a reduction in leaf-level stomatal conductance, when considered with energy balance in the whole canopy, should lead to decreases in transpiration and potential positive impacts on crop WUE.

The gradient of water vapor between a leaf and the atmosphere is considerably affected by the internal leaf water vapor pressure (e; $\mathrm{kPa}$ ) which is tightly coupled to leaf temperature $\left(\mathrm{T} ;{ }^{\circ} \mathrm{C}\right)$ and can be calculated from Teten's equation, $\mathrm{e}=0.61078^{*} \exp \left[17.269^{*} \mathrm{~T} /\right.$ $(\mathrm{T}+237.3)]$. Consequently, any factor affecting the energy balance and leaf or canopy temperature will directly affect water vapor pressure inside the leaves and ultimately its water use. Increases in air temperature will directly increase crop canopy temperature, leaf water vapor pressure, and evapotranspiration (ET).

Although there is evidence increasing $\mathrm{CO}_{2}$ increases water conservation at the leaf scale, these responses are tempered by competing processes at the whole-plant and/or ecosystem scale which in turn results in ET and soil water use being less affected by high $\mathrm{CO}_{2}$ than is conductance (Field et al., 1995). Increased ET at elevated $\mathrm{CO}_{2}$ has been reported by Hui et al. (2001). Compensatory effects between increased foliage temperature, derived from the changes in air temperature via the canopy energy balance, and increased LAI caused by $\mathrm{CO}_{2}$ enrichment created negligible to small ET changes (Allen et al., 2003). Evidence from controlled environment chambers with soybean canopies showed a $12 \%$ reduction in seasonal transpiration and $51 \%$ increase in WUE when grown in ambient and doubled $\mathrm{CO}_{2}$ (Jones et al., 1985). Observations of foliage temperatures in these chambers, measured by infrared thermometers, showed that foliage temperatures typically increased by 1 to $2^{\circ} \mathrm{C}$ (soybean), $1.5^{\circ} \mathrm{C}$ (dry bean), and $2^{\circ} \mathrm{C}$ (sorghum) to doubled $\mathrm{CO}_{2}$ (Pan, 1996; Prasad et al., 2002, 2006a). In a different study Allen et al. (2003) reported similar findings that soybean foliage temperatures were $1.3^{\circ} \mathrm{C}$ warmer at mid-day when exposed to doubled $\mathrm{CO}_{2}$. Comparable results between experiments in wheat (Triticum aestivum L.) have been found by Andre and du Cloux (1993) who reported 8\% decrease in transpiration of wheat in response to doubled $\mathrm{CO}_{2}$, and Hunsaker et al. (1996, 2000) who observed about a $4 \%$ reduction in ET with a 200 $\mu \mathrm{mol} \mathrm{mol}{ }^{-1} \mathrm{CO}_{2}$ increase in a FACE studies when water and $\mathrm{N}$ were limiting. In constrast, cotton (Gossypium hirsutum L.) showed no change in ET in a similar FACE experiment (Hunsaker et al., 1994), but cotton's growth response was much greater than that of wheat (e.g., Kimball et al., 2002). Reddy et al. (2000) observed transpiration of cotton was reduced by $8 \%$ when exposed to doubled $\mathrm{CO}_{2}$ and averaged over five temperature treatments in controlled-environment chambers, and Kimball and Idso (1983) found a 4\% reduction in seasonal water use at $650 \mu \mathrm{mol} \mathrm{mol}{ }^{-1} \mathrm{CO}_{2}$ vs. ambient in open-top chambers. FACE experiments in Illinois with soybean grown at 550 compared to $375 \mu \mathrm{mol} \mathrm{mol}{ }^{-1}$ showed a 9 to $16 \%$ decrease in ET with the range of differences caused by seasonal effects (Bernacchi et al., 2007). Analysis of their data reveals 12\% reduction over $3 \mathrm{yr}$. There are impacts of temperature on the degree of $\mathrm{CO}_{2}$ response. Soybean grown under a $\mathrm{CO}_{2}$ doubling at $28 / 18^{\circ} \mathrm{C}$ treatment (about the same mean temperature as the Illinois site) showed a $9 \%$ reduction in ET, but there was no reduction in ET with $\mathrm{CO}_{2}$ doubling at warm temperature treatment $40 / 30^{\circ} \mathrm{C}$ (Allen et al., 2003). Reduction in ET caused by changes in $\mathrm{CO}_{2}$ will be mediated by temperature. This is confirmed in rice (Oryza sativa L.) where Horie et al. (2000) summarized that doubling $\mathrm{CO}_{2}$ caused $15 \%$ reduction in ET at $26^{\circ} \mathrm{C}$, but increased ET at higher temperatures $\left(29.5^{\circ} \mathrm{C}\right)$. Exposure to higher temperatures reduces the impact of elevated $\mathrm{CO}_{2}$ on stomatal conductance and observations have shown that at 24 to $26^{\circ} \mathrm{C}$, WUE in rice increased by $50 \%$ with doubled $\mathrm{CO}_{2}$, and declined as air temperature increased.

To evaluate the potential impacts of climate change on crop ET there is a need for detailed studies on the sensitivity of ET to a combination of weather and plant variables. An example of this type of approach using the Penman-Monteith equation for ET as described by Allen et al. (2005) with alfalfa (Medicago sativa L.) as the reference crop and hourly weather data for the year 2000 from the AZMET station (Brown, 1987) at Maricopa, AZ (33'2'60" N, 112 W, 358 m elevation) was reported by Kimball (2007). When all other variables were held constant and only temperature was changed, reference ET increased about 3.4\%/C. Under climate change, relative humidity will remain constant more than absolute humidity (e.g., Dessler and Sherwood, 2009). Temperature increases with a constant relative humidity causes annual ET to change about $2.1 \% /{ }^{\circ} \mathrm{C}$. Changing absolute vapor pressure, due to result of changing precipitation patterns, would cause the ET to change $-0.2 \%$ per percent increase in absolute humidity. Changes in solar radiation are not reported in the IPCC report (IPCC, 2001); however, expected increases in average global rainfall implies increases in cloudiness leading to decreases in solar radiation impinging on crops. When solar radiation changes, the sensitivity of reference ET is $0.6 \%$ per $\%$ change in radiation for a clear day and and $0.4 \%$ per $\%$ change in radiation for a whole year using the meteorological data from Maricopa, AZ. In a sensitivity analysis for wind speed ET would change about $0.3 \%$ per $\%$ change in wind speed for a clear day and $0.4 \%$ per $\%$ change in wind speed for a whole year. Changes in stomatal conductance and leaf area have the same relative effect on ET, and increase ET by 0.09 and $0.16 \%$ per $\%$ change in either variable for a clear summer days and whole year, respectively.

Based on the sensitivity calculations of Kimball (2007) for "standard" alfalfa using weather from Maricopa, AZ, the combined effect of increases in average global temperature by $0.8^{\circ} \mathrm{C}$ (assuming constant relative humidity) and atmospheric $\mathrm{CO}_{2}$ concentration to nearly $450 \mu \mathrm{mol} \mathrm{mol}{ }^{-1}$ by 2040 are expected to increase ET about $1.9 \%$ for a clear summer day. Conversely, decrease in stomatal conductance of $10 \%$ caused by elevated $\mathrm{CO}_{2}$ concentrations to $450 \mu \mathrm{mol} \mathrm{mol}^{-1}$ with no change in temperature will decrease ET by about $0.9 \%$. 
Increasing temperature and $\mathrm{CO}_{2}$ are of the same magnitude but act in opposite directions causing the net changes on ET to be minimal.

Observations of water use in FACE experiments where $550 \mu \mathrm{mol} \mathrm{mol}{ }^{-1} \mathrm{CO}_{2}$ concentrations have been used have shown a reduction in water use by about 2 to $13 \%$ depending on species (Fig. 1). Interpolating linearly to $\mathrm{CO}_{2}$ concentrations of $450 \mu \mathrm{mol} \mathrm{mol}{ }^{-1}$ the corresponding reductions would be about one-third those observed in the FACE experiments (i.e., 1-4\%). Furthermore, the limitations in extrapolating FACE plot data to larger areas (e.g., discussion in Triggs et al., 2004), shows that crop water requirements under elevated $\mathrm{CO}_{2}$ are reduced only to a small extent.

Crop water use patterns and the timing of rain/irrigation events will affect the response to elevated $\mathrm{CO}_{2}$ under rainfed conditions. Bernacchi et al. (2007) observed that the loss of latent heat energy (LE, i.e., water vapor) from soybean at ambient $\mathrm{CO}_{2}$ levels in the FACE plots with adequate soil water was 10 to $60 \mathrm{~W} \mathrm{~m}^{-2}$ less compared to control plots. They observed when the control plots had exhausted their water supply water use declined. However, in the elevated $\mathrm{CO}_{2}$ plots the stomata remained open and the plants continued to transpire because of the water conservation compared to control plots. This allowed the FACE plots to continue to photosynthesize and grow for a few days longer while the control plants ceased growth. Under rain-fed agriculture, which often experiences periods of drought, the net impact of elevated concentrations of $\mathrm{CO}_{2}$ would be to enable conservation of soil water, thus sustaining crop productivity for more days than at today's $\mathrm{CO}_{2}$ levels.

Assessment of the change in irrigation requirement under scenarios of climate change is critical to long-range planning for water resource allocation since agriculture is one of the primary water users. There have been few attempts to estimate future changes in irrigation water requirements, defined as the difference between seasonal ET for a well-watered crop and the amounts of precipitation and soil water storage available during a growing season. Projected climate changes obtained from general circulation models (GCMs) were coupled with crop water use impacts resulting from decreased stomatal conductance caused by elevated $\mathrm{CO}_{2}$ in a simulation study (e.g., Allen et al., 1991; Izaurralde et al., 2003). Izaurralde et al. (2003) conducted a comprehensive assessment of climate change impacts on agricultural production and water resources of the conterminous United States using the EPIC crop growth model (Williams, 1995) to simulate growth and yield and future irrigation requirements of corn and alfalfa. Using the approach developed by Stockle et al. (1992a, 1992b), EPIC was modified to allow stomatal conductance to be reduced with increased $\mathrm{CO}_{2}$ concentration (28\% reduction corresponding to $560 \mu \mathrm{mol} \mathrm{mol}^{-1}$ $\mathrm{CO}_{2}$ ) along with increasing photosynthesis through improved radiation use efficiency. They used the climate change projections generated for 2030 by the Hadley Centre (HadCM2) GCM because its climate sensitivity and projections are in the midrange of most of the GCMs. For maize, they calculated irrigation requirements in 2030 would decrease in the Lower Colorado Basin by $-1 \%$ and increase in the Lower Mississippi Basin by $451 \%$ because of the change in temperature and humidity (Izaurralde et al., 2003). Even though there is variation in the sizes and baseline irrigation requirements among irrigation
Evapotranspiration

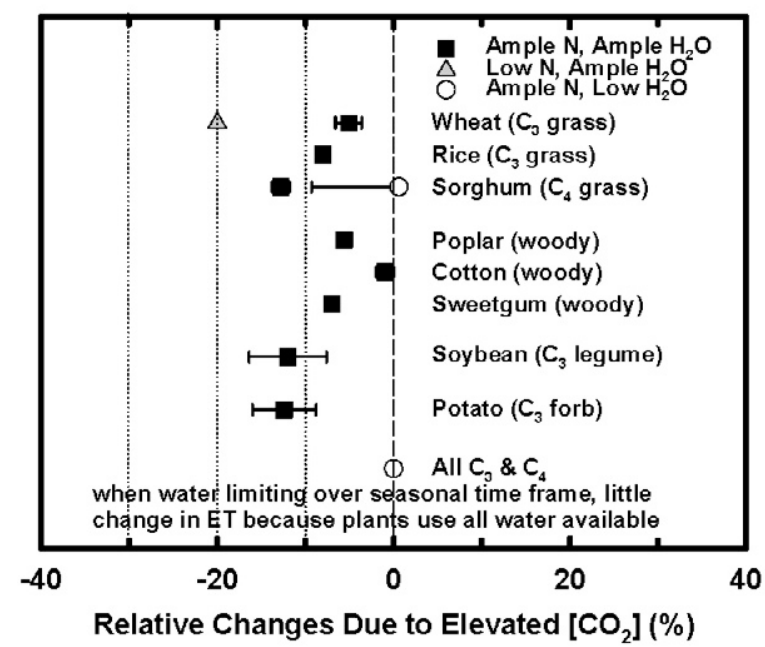

Fig. I. Relative changes in evapotranspiration due to elevated $\mathrm{CO}_{2}$ concentrations in FACE experiments at about $550 \mu \mathrm{mol}$ $\mathrm{mol}^{-1}$. Wheat and cotton data from Table 2 of Kimball et al. (2002); rice datum from Yoshimoto et al. (2005); sorghum datum from Triggs et al. (2004); poplar datum from Tommasi et al. (2002); sweetgum from Wullschleger and Norby (2001); soybean datum from Bernacchi et al. (2007); and potato datum from Magliulo et al. (2003).

basins they reported for the United States an increase of $64 \%$ if stomatal effects were ignored or $35 \%$ if included. Similar calculations for alfalfa showed overall irrigation requirements to increase $50 \%$ when stomatal effects were not considered in the model and 29\% with stomatal effects included.

Using observed sensitivity of soybean stomatal conductance to $\mathrm{CO}_{2}$ in a crop climate model, Allen (1990) used a crop simulation model and the accompanying sensitivity analysis of stomatal conductance to $\mathrm{CO}_{2}$ to demonstrate changes in $\mathrm{CO}_{2}$ from 330 to $800 \mu \mathrm{mol} \mathrm{mol}{ }^{-1}$ resulted in foliage temperature increases of about $1^{\circ} \mathrm{C}$ with low air vapor pressure deficit (VPD), but an increase of 2.5 to $4^{\circ} \mathrm{C}$ with air VPD in the range of 1.5 and $3 \mathrm{kPa}$, respectively. As VPD values increased above these levels, simulated foliage temperatures exceeded values observed at large VPD in the sunlit controlled-environment chambers (Allen, 1990; Prasad et al., 2002, 2006a; Allen et al., 2003). Experimental observation on soybean canopies showed that soybean canopies increased their conductance when exposed to progressively larger VPD (associated with higher temperature) so that observed canopy temperatures did not increase as much as predicted by the crop-climate model (Allen et al., 2003). The interaction of the positive impact of a doubling of $\mathrm{CO}_{2}$ to reduce ET about $9 \%$ at cool temperatures $\left(28 / 18^{\circ} \mathrm{C}\right)$ diminished and become negligible with temperature increased to $40 / 30^{\circ} \mathrm{C}$ and $44 / 34^{\circ} \mathrm{C}$. Exposure to higher temperatures from both experimental evidence and simulation models shows the $\mathrm{CO}_{2}$-induced benefit to conductance diminishes as temperatures increase.

Boote et al. (1997), using CROPGRO-Soybean model with hourly energy balance and stomatal conductance feedback to transpiration and leaf temperature (Pickering et al., 1995), studied the effects of $350 \mathrm{vs} .700 \mu \mathrm{mol} \mathrm{mol}{ }^{-1} \mathrm{CO}_{2}$ with weather data from Ohio and Florida. Simulated transpiration was reduced 11 to $16 \%$ for irrigated sites and $7 \%$ for a rainfed site, while ET was reduced 6 to $8 \%$ for irrigated sites and $4 \%$ for the rainfed site. Combining the information to simulate WUE 
showed an increase of 53 to $61 \%$, which closely matches the 50 to $60 \%$ increase for soybean WUE reported by Allen et al. (2003). Model simulations produced at mid-day a $1^{\circ} \mathrm{C}$ higher foliage temperature under doubled $\mathrm{CO}_{2}$, consistent with other studies. Smaller reductions in $\mathrm{T}$ and $\mathrm{ET}$ from the rainfed site were due to more effective and prolonged use of soil water and produced a larger yield response (44\%) for rainfed crop than for irrigated (32\%). Simulated reductions in transpiration were similar (11-16\%) as those measured (12\%) by Jones et al. (1985).

Water deficit conditions likely to occur under increasing variation of precipitation will increase the importance of understanding the interactions of $\mathrm{CO}_{2}$ enrichment with climatic factors of water supply and evaporative demand. An advantage of elevated $\mathrm{CO}_{2}$ will be evident first on reduced stomatal conductance which in turn leads to enhanced soil water conservation and less water stress detectable when crops are grown under conditions with periodic soil water deficit or under high evaporative demand. Reducing water stress has a positive impact on photosynthesis, growth, and yield and that has been documented for wheat (Wall et al., 2006) and sorghum (Ottman et al., 2001; Wall et al., 2001; Triggs et al., 2004). Sorghum showed significant $\mathrm{CO}_{2}$-induced enhancement of biomass and grain yield for water deficit treatments; however, exhibited no significant enhancement when grown with full-irrigation at the Arizona FACE project (Ottman et al., 2001). In these studies, stomatal conductance was reduced by 32 to $37 \%$ (Wall et al., 2001), while ET was reduced 13\% (Triggs et al., 2004). The potential of increasing water deficits caused by more variable precipitation patterns coupled with increasing $\mathrm{CO}_{2}$ and temperatures suggests we need to be addressing how cropping systems respond to the interactions of soil water, $\mathrm{CO}_{2}$, and temperature as part of adaptative management strategies.

\section{OZONE IMPACTS ON CROPS}

Although attention has been directed toward $\mathrm{CO}_{2}$ increases as part of the climate change process less attention has been given to tropospheric $\mathrm{O}_{3}$ even though these concentrations have increased in rural areas of the United States over the past $50 \mathrm{yr}$, and are forecast to continue to increase during the next 50 yr. Currently, the Midwest and eastern United States regions exhibit some of the highest rural $\mathrm{O}_{3}$ levels worldwide. Ozone concentrations increase toward the east and south, showing levels in Illinois exceed those in Nebraska, Minnesota, and Iowa. Only western Europe and eastern China have similar (high) levels. Argentina and Brazil and most of the Southern Hemisphere have much lower levels of ozone, and they are expected to see little increase in $\mathrm{O}_{3}$ over the next $50 \mathrm{yr}$. These increasing $\mathrm{O}_{3}$ levels will impact crop production and efforts to increase ozone tolerance will be important to maintain the competitiveness of U.S. growers. Future trends in global $\mathrm{O}_{3}$ concentrations are linked to IPCC scenarios, so that agricultural impacts from $\mathrm{O}_{3}$ can be considered along with the other components in climate change. Modeled predictions for $\mathrm{O}_{3}$ based on expected economic development and planned emission controls in individual countries estimate significant increases in annual mean surface $\mathrm{O}_{3}$ concentrations in the major agricultural areas of the Northern Hemisphere (Dentener et al., 2005).

Daytime ozone levels in the Midwest have steadily increased over the last $100 \mathrm{yr}$ and have climbed from $<10 \mathrm{nmol} \mathrm{mol}^{-1}$ to the present average of $60 \mathrm{nmol} \mathrm{mol}^{-1}$. Implementation of control measures on NOx and VOCs emissions in North America and Western Europe are reducing peak ozone levels; however, global background tropospheric ozone concentrations continue to rise (Ashmore, 2005). Many plants suffer from ozone toxicity and greenhouse and small chamber studies have shown that the major agronomic crops, soybean, wheat, peanut (Arachis hypogaea L.), and cotton are the most sensitive (Ashmore, 2002).

Soybean has been the most extensively studied crop for $\mathrm{O}_{3}$ effects. Its response varies greatly among cultivars, and is influenced by the $\mathrm{O}_{3}$ profile and dynamics, nutrient and moisture conditions, and atmospheric $\mathrm{CO}_{2}$ concentrations. The large volume of information on soybean response has been summarized in a meta-analysis of more than 50 studies on soybean, grown in controlled environment chambers at chronic levels of $\mathrm{O}_{3}$, and they reveal exposure to high levels $\left(>75 \mathrm{nmol} \mathrm{mol}^{-1}\right)$ of $\mathrm{O}_{3}$ decreases photosynthesis, dry matter, and yield (Morgan et al., 2003; Morgan et al., 2004). Exposure to mild chronic levels $\left(40-60 \mathrm{nmol} \mathrm{mol}^{-1}\right)$ produces similar responses, with dry matter and yield decreasing linearly with $\mathrm{O}_{3}$ concentration (Morgan et al., 2003). Mills et al. (2000) developed an exposure/response relationship that serves as the basis for these relationships. The meta-analysis shows that chronic $\mathrm{O}_{3}$ lowers the carbon uptake capacity in soybean through a reduction of photosynthetic capacity and leaf area. Exposure of soybean to chronic $\mathrm{O}_{3}$ levels led to shorter plants with reduced dry mass and fewer pods containing fewer and smaller seeds. It has been observed that $\mathrm{O}_{3}$ damage increases with the age of the soybean which is consistent with the hypothesis $\mathrm{O}_{3}$ effects are cumulative over time (Adams et al., 1996; Miller et al., 1998). This additive effect through the season may indicate a greater sensitivity during seed filling (Tingey et al., 2002). Across these studies there was no indication of interactions with other stresses, even those expected to lower stomatal conductance and the pathway for $\mathrm{O}_{3}$ entry into the leaf (Medlyn et al., 2001). A positive impact from elevated $\mathrm{CO}_{2}$ and the resultant effect on stomatal conductance was to reduce the impacts from increasing $\mathrm{O}_{3}$ (Heagle, 1989).

Plant growth responses from chamber studies can be different compared to the open field studies (Long et al., 2006), and the results from chamber experiments have been questioned as the basis for estimating yield losses caused by $\mathrm{O}_{3}$ damage (Elagoz and Manning, 2005). Exposure of soybean in FACE experiments to a $20 \%$ increase above ambient $\mathrm{O}_{3}$ levels shows $\mathrm{O}_{3}$-induced yield losses were nearly as large as those found with open air treatment. It was observed in 2003 in central Illinois that the background $\mathrm{O}_{3}$ level was substantially lower throughout the growing season, averaging $45 \mathrm{nmol} \mathrm{mol}^{-1}$, and increasing $\mathrm{O}_{3}$ levels by $20 \%$ raised the concentration to the previous $10 \mathrm{yr}$ average. Yields from plots exposed to elevated $\mathrm{O}_{3}$ in 2003 , were reduced approximately $25 \%$ (Morgan et al., 2006). Evaluation of the growth components in the soybean FACE showed a significant decrease in leaf area (Dermody et al., 2006), loss of photosynthetic capacity during grain filling, and earlier onset of leaf senescence (Morgan et al., 2004). These observations help explain why yield loss may be more closely linked to decreased seed size than decreased seed number (Morgan et al., 2006). Yield losses observed from the Illinois soybean FACE experiment between 2002 and 2005 averaged $0.5 \%$ per nmol mol${ }^{-1}$ increase above the $30 \mathrm{nmol} \mathrm{mol}^{-1}$ threshold and is twice the sensitivity to $\mathrm{O}_{3}$ exposure measured 
Table 2. Cardinal base and optimum temperatures $\left({ }^{\circ} \mathrm{C}\right)$ for vegetative development and reproductive development, optimum temperature for vegetative biomass, optimum temperature for maximum grain yield, and failure (ceiling) temperature at which grain yield fails to zero yield, for economically important crops. The optimum temperatures for vegetative production, reproductive (grain) yield, and failure point temperatures represent mean temperatures from studies where diurnal temperature range was up to $10^{\circ} \mathrm{C}$.

\begin{tabular}{|c|c|c|c|c|c|c|c|}
\hline Crop & $\begin{array}{c}\text { Base temp. } \\
\text { veg. }\end{array}$ & $\begin{array}{l}\text { Opt. temp. } \\
\text { veg. }\end{array}$ & $\begin{array}{l}\text { Base temp. } \\
\text { repro. }\end{array}$ & $\begin{array}{l}\text { Opt. temp. } \\
\text { repro. }\end{array}$ & $\begin{array}{l}\text { Opt. temp. } \\
\text { range veg. prod. }\end{array}$ & $\begin{array}{l}\text { Opt. temp. } \\
\text { range reprod. yield }\end{array}$ & $\begin{array}{l}\text { Failure temp. } \\
\text { reprod. yield }\end{array}$ \\
\hline Maize & $8^{\dagger}$ & $34 \dagger$ & $8^{\dagger}$ & $34^{\dagger}$ & & $18-25 \ddagger$ & $35 \S$ \\
\hline Sorghum & $8 t+t t$ & $34 t+t t$ & $8 t+t t$ & $31+t+t$ & $26-34 \S \S \S \S$ & $25++\neq+$, กाтा & $35+t+$ \\
\hline Bean & & & & & $23 \# \# \# \#$ & 23-24\#\#\#\#,t+t+t+† & $32 \# \# \# \#$ \\
\hline Cotton & 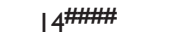 & $37^{\# \# \#}$ & 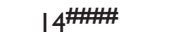 & $28-30^{\# \# \# ~}$ & $34 t+t t t$ & $25-26$ 林+甘 & $35 \S \S \S \S \S$ \\
\hline Peanut & । Оศศกศा & & & & & & \\
\hline Rice & $8 \ddagger+$ & $36 \S \S \S$ & 8 柆 & 33 栝 & 33भाभा & 23-26§§§,\#\#\# & $35-36 \S \S \S$ \\
\hline Soybean & $7 \pi$ & $30 \pi$ & $6^{\#}$ & $26^{\#}$ & $25-37+t$ & $22-24 t \dagger$ & $39 \neq$ \\
\hline Wheat & $0 \S \S$ & $26 \S \S$ & ן§ & $26 \S \S$ & 20-30กा & $15^{\# \#}$ & $34 t+t$ \\
\hline
\end{tabular}

† Kiniry and Bonhomme (1991), Badu-Apraku et al. (1983). $\quad$ †† Tashiro and Wardlaw (1990).

$\ddagger$ Muchow et al. (1990).

$\S$ Herrero and Johnson (1980).

TI Hesketh et al. (1973).

\# Boote et al. (1998).

†† Boote et al. (1997).

怙Boote et al. (2005).

$\S \S$ Hodges and Ritchie (1991).

ПТा Kobza and Edwards (1987).

\#\# Chowdhury and Wardlaw (1978).
†† Tashiro and Wardlaw (1990).
㧊 Alocilja and Ritchie (1991).

$\S \S \S$ Baker et al. (1995).

ПТा Matsushima et al. (1964).

\#\#\# Horie et al. (2000).

††† Alagarswamy and Ritchie (1991).

㧊 Prasad et al. (2006a).

$\S \S \S \S$ Maiti (1996).

ণाাाT Downs (1972).

\#\#\#\# K. R. Reddy et al. (1999, 2005).
†††† V. R. Reddy et al. (1995a)

抽市 K. R. Reddy et al. (2005).

$\S \S \S \S \S$ K. R. Reddy et al. (1992a, 1992b).

ๆाभाT Ong (1986).

\#\#\#\#\# Prasad et al. (2002).

†††††† Laing et al. (1984). in growth chamber studies (Ashmore, 2002). Ozone damage in an average year may cause soybean yield losses of 10 to $25 \%$ in the Midwest, with increased yield losses in some years. Another meta-analysis for rice (Oryza sativa L.) was conducted by Ainsworth (2008) found the response to be similar to soybean with significant decreases in net photosynthesis, biomass, grain number and mass, and yield. This summary contradicts the previous observation that rice is less sensitive to $\mathrm{O}_{3}$ than other crops (Wang and Mauzerall, 2004). A summary of $\mathrm{O}_{3}$ exposure on yield and yield parameters from studies before 2000 are presented in Black et al. (2000) showing that, in addition to soybean, yield of $\mathrm{C}_{3}$ crops, for example, wheat, oat (Avena sativa L.), French and snap bean (Phaseolus vulgaris L.), pepper (Capsicum annuum L.), rape (Brassica napus L.), and various cucurbits are highly sensitive to chronic $\mathrm{O}_{3}$ exposure. Cotton yields are also highly sensitive to $\mathrm{O}_{3}$ (Temple, 1990). There have been a few reports showing maize yield is reduced by $\mathrm{O}_{3}$ (e.g., Rudorff et al., 1996); however, $\mathrm{C}_{4}$ crops are generally considered less sensitive. In spite of these few reports the current annual economic losses in corn caused by exposure to $\mathrm{O}_{3}$ in the United States and China is estimated to be in excess of one billion dollars (Van Dingenen et al., 2008).

While the research on elevated $\mathrm{CO}_{2}$ on stomatal conductance has been extensive there has been less conducted on the effects of elevated $\mathrm{O}_{3}$, but some research has provided some insights into these $\mathrm{O}_{3}$ impacts. Barnes et al. (1995) and Balaguer et al. (1995) studied stomatal conductance response of wheat exposed to $700 \mu \mathrm{mol} \mathrm{mol}{ }^{-1} \mathrm{CO}_{2}, 75 \mathrm{nmol} \mathrm{mol}{ }^{-1} \mathrm{O}_{3}$, and increased $\mathrm{CO}_{2}+\mathrm{O}_{3}$ in controlled environment chambers. Exposure to higher $\mathrm{O}_{3}$ reduced conductance by about $20 \%$, while both $\mathrm{CO}_{2}$ and $\mathrm{CO}_{2}+\mathrm{O}_{3}$ reduced conductance by $40 \%$. Wheat was exposed to $680 \mu \mathrm{mol} \mathrm{mol}{ }^{-1} \mathrm{CO}_{2}, 50$ or $90 \mathrm{nmol} \mathrm{mol}{ }^{-1} \mathrm{O}_{3}$, and the combined effect of $\mathrm{CO}_{2}+\mathrm{O}_{3}$ using open-top chambers revealed that these treatments caused reductions in stomatal conductance of nearly $50 \%$ with year and time after sowing causing a variation in the response (Donnelly et al., 2000). Observations of stomatal conductance in potato (Solanum turberosum L.) showed a reduction of about $50 \%$ by $680 \mu \mathrm{mol} \mathrm{mol}{ }^{-1} \mathrm{CO}_{2}$ with similar reductions with elevated $\mathrm{CO}_{2}$ combined with elevated $\mathrm{O}_{3}$; however, their results were variable and inconsistent among treatments (Lawson et al., 2002; Finnan et al., 2002). Noormets et al. (2001) measured stomatal conductance of aspen (Populus tremuloides Michx.) leaves using a FACE chamber combining $\mathrm{CO}_{2}$ and $\mathrm{O}_{3}$ treatments. The effect on stomatal conductance varied with leaf age and aspen clone and revealed the following responses: Control $>\mathrm{O}_{3}>\mathrm{CO}_{2}+\mathrm{O}_{3}>\mathrm{CO}_{2}$. These results are not consistent and recent results from a soybean FACE experiment where $\mathrm{O}_{3}$ was elevated by $50 \%$ above ambient conditions showed no significant effect of $\mathrm{O}_{3}$ on stomatal conductance (Bernacchi et al., 2006). Observations from chamber studies comparing elevated $\mathrm{O}_{3}$ vs. zero $\mathrm{O}_{3}$ on stomatal conductance have shown that reductions can occur. However, observations of field-grown plants exposed to present-day ambient levels of $\mathrm{O}_{3}$ (considerably higher than zero) would suggest that changes in stomatal conductance resulting from $\mathrm{O}_{3}$ levels expected by 2030 would be rather small.

Ozone is changing throughout the United States and understanding these impacts and interactions with other climate variables will help develop adaptive strategies to reduce potential yield loss. It is critical in these studies that the interaction with other variables $\left(\mathrm{CO}_{2}\right.$, temperature, and soil water availability) be part of the analysis.

\section{Temperature Effects on Crop Plants}

Crop species respond differently to temperature throughout their life cycles. Each species has a defined range of maximum and minimum temperatures within which growth occurs and an optimum temperature at which plant growth progresses at its fastest rate (Table 2). Growth rates slow as temperature increases above the optimum and cease when plants are exposed to their maximum (ceiling) temperature. Vegetative development (node and leaf appearance rate) hastens as temperatures increase up to the species optimum temperature. Vegetative development usually has a higher optimum temperature than reproductive development. Progression of a crop through phenological phases is accelerated by increasing temperatures up to the species-dependent optimum 
Table 3. Percent grain yield response to increased temperature $\left(0.8^{\circ} \mathrm{C}\right)$, increased $\mathrm{CO}_{2}\left(380-440 \mu \mathrm{mol} \mathrm{mol}{ }^{-1}\right)$, net effect of temperature and increased $\mathrm{CO}_{2}$ on irrigated yield assuming additivity, and change in evaptranspiration (ET) of rainfed crops with temperature and $\mathrm{CO}_{2}$. Current mean air temperature during reproductive growth is shown in parentheses for each crop/region to give starting reference, although yield of all the cereal crops declines with a temperature slope that originates below current mean air temperatures during grain filling. Data are from Hatfield et al. (2008).

\begin{tabular}{|c|c|c|c|c|c|}
\hline Crop & Temperature $\left(0.8^{\circ} \mathrm{C}\right)$ & $\mathrm{CO}_{2}(380-440 \mu \mathrm{mol} \mathrm{mol}-1)^{\dagger}$ & Temp/CO $\mathrm{CO}_{2}$ combined irrigated & Temp on ET $\ddagger$ & $\mathrm{CO}_{2}$ on $\mathrm{ET} \S$ \\
\hline & \multicolumn{5}{|c|}{$-\%$ change- } \\
\hline Maize-Midwest $\left(22.5^{\circ} \mathrm{C}\right)$ & -2.5 & +1.0 & -1.5 & $+1.2^{2}$ & \\
\hline Maize-South $\left(26.7^{\circ} \mathrm{C}\right)$ & -2.5 & +1.0 & -1.5 & $+1.2^{2}$ & \\
\hline Soybean-Midwest $\left(22.5^{\circ} \mathrm{C}\right)$ & +1.7 & +7.4 & +9.1 & $+1.2^{2}$ & -2.1 \\
\hline Soybean-South $\left(26.7^{\circ} \mathrm{C}\right)$ & -2.4 & +7.4 & +5.0 & $+1.2^{2}$ & -2.1 \\
\hline Wheat-Plains $\left(19.5^{\circ} \mathrm{C}\right)$ & -4.4 & +6.8 & +2.4 & $+1.2^{2}$ & -1.4 \\
\hline Rice-South $\left(26.7^{\circ} \mathrm{C}\right)$ & -8.0 & +6.4 & -1.6 & $+1.2^{2}$ & -1.7 \\
\hline Sorghum (full range) & -6.2 & +1.0 & -5.2 & $+1.2^{2}$ & -3.9 \\
\hline Cotton-South $\left(26.7^{\circ} \mathrm{C}\right)$ & -3.5 & +9.2 & +5.7 & $+1.2^{2}$ & -1.4 \\
\hline Peanut-South $\left(26.7^{\circ} \mathrm{C}\right)$ & -3.3 & +6.7 & +3.4 & $+1.2^{2}$ & \\
\hline Bean-relative to $23^{\circ} \mathrm{C}$ & -5.8 & +6.1 & +0.3 & $+1.2^{2}$ & \\
\hline
\end{tabular}

$\uparrow$ Response to $\mathrm{CO}_{2}$ increment, with Michaelis-Menten rectangular hyperbola interpolation.

$\ddagger$ Response of ET to temperature increment $1.489 \times 0.8^{\circ} \mathrm{C}$ from sensitivity of ASCE "standard" ET equation for nonwater-stressed alfalfa (Kimball, 2007).

$\S$ Adapted from Table 2.7 of Hatfield et al. (2008) for mostly nonwater-stressed conditions.

temperature. There are differences among annual (nonperennial) crop species in their cardinal temperature values as shown in Table 2. Values reported in Table 2 represent conditions in which temperature is the only limiting variable. It is important to realize that plant temperatures can be quite different than air temperatures and can be warmer than air under water stressed conditions or cooler than air under adequate soil water conditions. A recent review by Hatfield et al. (2004) provides a summary of the current use of plant temperatures to quantify water stress in plants. Plant temperatures are measured with either attached thermometers to the leaf that are difficult to maintain or with relatively expensive infrared thermometers, and therefore plant temperatures have been observed much less often than air temperatures. Consequently, evaluations of plant responses to changes in temperature have been focused on air temperature rather than plant or canopy temperatures, including the values given in Table 2.

Exposure to higher temperatures causes faster development in nonperennial crops, which does not translate into an optimum for maximum production because the shorter life cycle means smaller plants, a shortened reproductive phase duration, and reduced yield potential because of reduced cumulative light interception during the growing season. Observations across species have shown optimum temperatures for yield are generally lower than the optimum temperature for leaf appearance rate, vegetative growth, or reproductive progression (Table 2). Yield may be impacted when temperatures fall below or above specific thresholds at critical times during development. The duration of the crop life cycle is determined by temperature and the location of specific cultivars to given production zones is a reflection of their specific temperature response. Another factor that has a major role in life cycle progression in many crops, especially for soybean, is the daylength sensitivity.

One of the critical phenological stages for high temperature impacts is the reproductive stage because of the effect on pollen viability, fertilization, and grain or fruit formation. Yield potential will be affected by chronic exposures to high temperatures during the pollination stage of initial grain or fruit set. Temperature extremes during the reproductive stage of development can produce some of the largest impacts on crop production. Schlenker and Roberts (2009) have emphasized the importance of considering the nonlinearity of temperature effects on yield (the slope of the decline in yields above the optimum temperature is often steeper than the incline below it) in projecting climate change impacts. Temperature effects on individual species are discussed in the following section.

\section{Temperature Effects on Individual Species}

Exposure to temperature changes will affect all plants differently because of their unique temperature response. Climate change scenarios reveal temperatures will increase and the chance of plants being exposed to higher temperature extremes will be more likely. We have summarized the effects of temperature on different species important to world food, feed, and fiber production.

\section{Maize}

One of the most studied crops in terms of temperature response is maize and increasing temperature shortens the life cycle and duration of the reproductive phase causing a reduction in grain yield (Badu-Apraku et al., 1983; Muchow et al., 1990). Using both observed and simulated maize yields, Muchow et al. (1990) reported highest grain yields were from locations with relatively cool growing season mean temperatures $\left(18.0-19.8^{\circ} \mathrm{C}\right.$ at Grand Junction, CO), compared to warmer sites, for example, Champaign, IL $\left(21.5-24.0^{\circ} \mathrm{C}\right)$, or warm tropical sites $\left(26.3-28.9^{\circ} \mathrm{C}\right)$. This causes the simulated yields in the central Corn Belt to decrease 5 to $8 \%$ per $2^{\circ} \mathrm{C}$ temperature increase which leads to the prediction that a temperature rise of $0.8^{\circ} \mathrm{C}$ over the next $30 \mathrm{yr}$ in the Midwest could decrease grain yields by 2 to $3 \%$ (2.5\%, Table 3 ) assuming no complicating effect from soil water limitations. Their results may have underestimated the potential yield reduction with rising temperature because they did not incorporate temperature modifications to assimilation rate or respiration nor did they account for failures in grain-set due to rising temperature (Muchow et al., 1990). Lobell and Field (2007) separated the effects of temperature and rainfall using records from 1961 to 2002 and found an $8.3 \%$ yield reduction per $1^{\circ} \mathrm{C}$ rise in temperature. Runge (1968) observed maize yields were responsive to interactions of daily maximum temperature and rainfall $25 \mathrm{~d}$ prior and $15 \mathrm{~d}$ after anthesis. These interactions revealed when rainfall 
was low (zero to $44 \mathrm{~mm}$ per $8 \mathrm{~d}$ ), yield was reduced by 1.2 to $3.2 \%$ per $1^{\circ} \mathrm{C}$ rise. Conversely, when temperatures were warm $\left(\mathrm{T}_{\max }\right.$ of $35^{\circ} \mathrm{C}$ ), yield was reduced $9 \%$ per $25.4 \mathrm{~mm}$ decline in rainfall.

Temperature effects on pollination and kernel set may be one of the critical responses related to climate change. Pollen viability decreases when exposure to temperatures above $35^{\circ} \mathrm{C}$ occurs (Herrero and Johnson, 1980; Schoper et al., 1987; Dupuis and Dumas, 1990).The critical duration of pollen viability (before silk reception) is a function of pollen moisture content and is strongly dependent on vapor pressure deficit (Fonseca and Westgate, 2005). Although there is limited data on sensitivity of kernel set in maize to elevated temperature, the in vitro evidence suggests that the thermal environment during endosperm cell division phase ( $8-10 \mathrm{~d}$ postanthesis) is critical (Jones et al., 1984). Temperatures of $35^{\circ} \mathrm{C}$ compared to $30^{\circ} \mathrm{C}$ during the endosperm division phase reduced subsequent kernel growth rate (potential) and final kernel size, even after the plants were returned to $30^{\circ} \mathrm{C}$ (Jones et al., 1984). Exposure to temperatures above $30^{\circ} \mathrm{C}$ damaged cell division and amyloplast replication in maize kernels which reduced the strength of the grain sink and ultimately yield (Commuri and Jones, 2001). In maize, leaf photosynthesis rate has a high temperature optimum of 33 to $38^{\circ} \mathrm{C}$ with no sensitivity of quantum efficiency to elevated temperature (Oberhuber and Edwards, 1993; Edwards and Baker, 1993), and photosynthesis rate is reduced above $38^{\circ} \mathrm{C}$ (Crafts-Brandner and Salvucci, 2002). Ben-Asher et al. (2008) evaluated high temperature effects on sweet corn in controlled environment chambers and found highest photosynthetic rates occurred at temperatures of $25 / 20$ while at $40 / 35^{\circ} \mathrm{C}$ (light/dark) photosynthetic rates were 50 to $60 \%$ lower. They also observed that photosynthetic rate declined for each $1^{\circ} \mathrm{C}$ increase in temperature above $30^{\circ} \mathrm{C}$.

\section{Soybean}

Optimium temperatures for the postanthesis phase of soybean has a low optimum temperature of about $23^{\circ} \mathrm{C}$ which results in the life cycle being slower and longer when mean daily temperatures exceed $23^{\circ} \mathrm{C}$ (Pan, 1996; Grimm et al., 1994). Optimum cardinal temperature of $23^{\circ} \mathrm{C}$ for the postanthesis period is close to the single seed growth rate $\left(23.5^{\circ} \mathrm{C}\right)$ optimum temperature reported by Egli and Wardlaw (1980), and the same as the $23^{\circ} \mathrm{C}$ optimum temperature for seed size (Egli and Wardlaw, 1980; Baker et al., 1989; Pan, 1996; Thomas, 2001; Boote et al., 2005). Increasing the mean temperature above $23^{\circ} \mathrm{C}$ causes seed growth rate, seed size, and intensity of partitioning to grain (seed HI) to decrease until all of the parameters fall to zero at a mean temperature of $39^{\circ} \mathrm{C}$ (Pan, 1996; Thomas, 2001).

The cardinal temperature values for soybean are lower than those of maize and the values used for preanthesis reproductive development (time to anthesis) have a base of 6 and $26^{\circ} \mathrm{C}$ optimum as currently used in CROPGRO-soybean model (Boote et al., 1998). These are similar to the values of 2.5 and $25.3^{\circ} \mathrm{C}$ reported by Grimm et al. (1993). Using these temperature relationships for grain development as reported by Egli and Wardlaw (1980) for temperature effect on seed growth sink strength and the Grimm et al. $(1993,1994)$ derivation of temperature effects on reproductive development, the CROPGRO model predicts the highest grain yield of soybean at 23 to $24^{\circ} \mathrm{C}$, with progressive decline in yield, seed size, and harvest index (HI) with temperature increases above this optimum range and finally showing no yield at $39^{\circ} \mathrm{C}$ (Boote et al., $1997,1998)$. An analysis of 829 sites across the United States extracted from regional soybean yield trials (Piper et al., 1998) revealed that yield produced per day of season relative to mean air temperature showed the highest productivity at $22^{\circ} \mathrm{C}$.

Exposure to high temperatures during the pollination stage has deleterious effects on pollen growth and survival. Viability of soybean pollen is reduced by exposure to instantaneous temperatures above $30^{\circ} \mathrm{C}\left(\mathrm{T}_{\mathrm{opt}}\right)$, but show a long gradual decline until failure at $47^{\circ} \mathrm{C}$ (Salem et al., 2007). Averages among many cultivars show cardinal temperatures $\left(\mathrm{T}_{\mathrm{b}}, \mathrm{T}_{\mathrm{opt}}, \mathrm{T}_{\max }\right)$ of 13.2, 30.2, and $47.2^{\circ} \mathrm{C}$, respectively, for pollen germination and for pollen tube growth of $12.1,36.1$, and $47.0^{\circ} \mathrm{C}$, respectively. Differences in cardinal temperatures and tolerance of elevated temperature among cultivars were not significant. When soybean growth was compared at $38 / 30$ vs. $30 / 22^{\circ} \mathrm{C}$ (day/night) temperatures, exposure to elevated temperatures reduced pollen production by $34 \%$, pollen germination by $56 \%$, and pollen tube elongation by $33 \%$ (Salem et al., 2007). Temperatures above $23^{\circ} \mathrm{C}$ show a progressive reduction in seed size (single seed growth rate) with a reduction in fertility above $30^{\circ} \mathrm{C}$ leading to a reduced seed $\mathrm{HI}$ at temperatures above $23^{\circ} \mathrm{C}$ (Baker et al., 1989).

Potential impacts of climate change through temperature on soybean are strongly related to mean temperatures during the postanthesis phase of soybean. In the upper Midwest, where mean soybean growing season temperatures are currently around $22.5^{\circ} \mathrm{C}$, soybean yield may increase. However, for the southern United States with current growing season temperatures of 25 to $27^{\circ} \mathrm{C}$, soybean yields are expected to decline with increased warming, $2.4 \%$ for $0.8^{\circ} \mathrm{C}$ increase from $26.7^{\circ} \mathrm{C}$ current mean. This is similar to the observations from Lobell and Field (2007) who reported a $1.3 \%$ decline in soybean yield per $1^{\circ} \mathrm{C}$ increase in temperature. Temperature impacts on soybean production cannot be ignored and changes in management systems to limit exposure to high temperatures during pollination would benefit yield.

\section{Wheat}

Rising temperatures will decrease the length of grain-filling period of wheat and other small grains (Sofield et al., 1974, 1977; Chowdhury and Wardlaw, 1978; Goudriaan and Unsworth, 1990). Shortened grain filling duration was attributed to factors other than assimilate limitation (Sofield et al., 1974; 1977). If we assume that daily photosynthesis is unchanged, then yield will decrease in direct proportion to the shortening of grain filling period. Evidence for the temperature effect is already seen in higher wheat yield potential in northern Europe than in the midwestern United States. Rising temperature effects on photosynthesis are an additional reduction factor on wheat yield, because of the linkage with water deficit effects (Paulsen, 1994).

Optimum temperature ranges for photosynthetic rate in wheat is 20 to $30^{\circ} \mathrm{C}$ (Kobza and Edwards, 1987) and is $10^{\circ} \mathrm{C}$ higher than the optimum temperature $\left(15^{\circ} \mathrm{C}\right)$ for grain yield and single grain growth rate (Chowdhury and Wardlaw, 1978). Pushpalatha et al. (2008) observed that rubisco activity decreased in wheat plants with a reduction in the photosynthetic rate when wheat plants were exposed to high temperatures. Increases of temperature above 25 to $35^{\circ} \mathrm{C}$, common during grain filling of wheat, will shorten the grain filling period and reduce wheat yields. Chowdhury and Wardlaw (1978) observed a nonlinear slope of 
reduction in grain filling period to the mean temperatures and when this was applied to the wheat growing regions of the Great Plains, the projected reduction in yield is $7 \%$ per $1^{\circ} \mathrm{C}$ increase in air temperature between 18 and $21^{\circ} \mathrm{C}$ and $4 \%$ per $1^{\circ} \mathrm{C}$ when air temperatures increase above $21^{\circ} \mathrm{C}$. These projections do not consider any additional reduction caused by temperature effects on photosynthesis or grain-set. A similar set of responses were found by Lawlor and Mitchell (2000) who observed temperature increases of $1^{\circ} \mathrm{C}$ rise would shorten reproductive phase by $6 \%$ and grain filling duration by $5 \%$ causing a proportion reduction in grain yield and HI. Observations from nine sites in Europe for spring wheat revealed a $6 \%$ decrease in yield per $1^{\circ} \mathrm{C}$ temperature rise (Bender et al., 1999). When these temperature increases are extrapolated to the global scale a $5.4 \%$ decrease in wheat yield per $1^{\circ} \mathrm{C}$ increase in temperature is expected (Lobell and Field, 2007). Exposure to $36 / 31^{\circ} \mathrm{C}$ temperatures for only 2 to $3 \mathrm{~d}$ before anthesis created small unfertilized kernels with symptoms of parthenocarpy, small shrunken kernels with notching, and chalking of kernels (Tashiro and Wardlaw, 1990). A recent summary by Wheeler et al. (2000) on temperature effects during the grainfilling period of wheat found a linear decrease in grain yield with increasing mean temperature.

One of the observed changes in temperature is an increase in nighttime temperatures. When temperatures increased above $14^{\circ} \mathrm{C}$ there was a decreased photosynthesis after $14 \mathrm{~d}$ of stress causing grain yields to decrease linearly with increasing nighttime temperatures from 14 to $23^{\circ} \mathrm{C}$ which in turn leads to lower HI's (Prasad et al., 2008). In their studies, when nighttime temperatures increased above $20^{\circ} \mathrm{C}$ there was a decrease in spikelet fertility, grains per spike, and grain size.

\section{Rice}

Temperature response of rice has been well documented (Baker and Allen, 1993a, 1993b; Baker et al., 1995; Horie et al., 2000). When temperature increases from a base of $8^{\circ} \mathrm{C}$ to $36-40^{\circ} \mathrm{C}$ (the thermal threshold of survival) there is an increase in leaf appearance rate (Alocilja and Ritchie, 1991; Baker et al., 1995), biomass increases until temperatures reach $33^{\circ} \mathrm{C}$ (Matsushima et al., 1964); however, grain formation and yield is maximum at the optimum temperature of $25^{\circ} \mathrm{C}$ (Baker et al., 1995). Baker et al. (1995) concluded from their sunlit controlledenvironment chambers experiments that the optimum mean temperature for grain formation and grain yield of rice is $25^{\circ} \mathrm{C}$ and grain yield is reduced $10 \%$ per $1{ }^{\circ} \mathrm{C}$ temperature increase above $25^{\circ} \mathrm{C}$ until 35 to $36^{\circ} \mathrm{C}$ mean temperature when no yield is obtained. In their experiments they used a $7^{\circ} \mathrm{C}$ day/night temperature differential (Baker and Allen, 1993a; Peng et al., 2004). Exposure to temperatures above $25^{\circ} \mathrm{C}$ causes a yield decline due to shorter grain filling duration (Chowdhury and Wardlaw, 1978; Snyder, 2000). Further increase in temperature above $25^{\circ} \mathrm{C}$ causes progressive failure to produce filled grains caused by reduced pollen viability and pollen production (Kim et al., 1996; Matsui et al., 1997; Prasad et al., 2006b). Viability of pollen and production declines as daytime maximum temperature $\left(\mathrm{T}_{\max }\right.$ ) exceeds $33^{\circ} \mathrm{C}$ and is zero at $\mathrm{T}_{\text {max }}$ of $40^{\circ} \mathrm{C}$ ( Kim et al., 1996). Flowering of rice occurs near mid-day which makes $T_{\max }$ a good indicator of heat-stress on spikelet sterility. Exposure to temperatures above $33^{\circ} \mathrm{C}$ in rice within 1 to $3 \mathrm{~h}$ after anthesis (dehiscence of the anther, shedding of pollen, germination of pollen grains on stigma, and elongation of pollen tubes) can have negative impacts on reproduction (Satake and Yoshida, 1978). Current observations in rice reveal that anthesis occurs between about 0900 to $1100 \mathrm{~h}$ in rice (Prasad et al., 2006b).

Grain size of rice remains relatively constant and declines slowly with increasing temperatures, until the pollination failure point (Baker and Allen, 1993a). There is no difference in the rice ecotypes, japonica and indica, in their upper temperature threshold (Snyder, 2000; Prasad et al., 2006b); however, the indica types are more sensitive to night temperatures $<19^{\circ} \mathrm{C}$ (Snyder, 2000). There are significant genotypic variations in heat tolerance for percent filled grains, pollen production, pollen shed, and pollen viability based on screening of rice genotypes and ecotypes for heat tolerance $\left(33.1 / 27.3^{\circ} \mathrm{C}\right.$ vs. $28.3 / 21.3^{\circ} \mathrm{C}$ mean day/night temperatures) (Prasad et al.,2006b). Exposure to this increase in temperature for 14 cultivars caused a 9 to $86 \%$ reduction in spikelet fertility, 0 to $93 \%$ reduction in grain weight per panicle, and 16 to $86 \%$ reduction in HI. As expected the most tolerant cultivar showed the smallest decreases in spikelet fertility, grain yield, and HI to elevated temperature. Cheng et al. (2010) combined increased $\mathrm{CO}_{2}\left(360\right.$ or $\left.680 \mu \mathrm{mol} \mathrm{mol}^{-1}\right)$ and high night temperatures $\left(22\right.$ or $32^{\circ} \mathrm{C}$ with a daytime temperature of $32^{\circ} \mathrm{C}$ ) and found that (i) high night temperatures increased living leaf $\mathrm{N}$ concentration and leaf area and caused higher photosynthetic capacity during the last stage of growth; (ii) carbon assimilation increased with higher night temperatures despite the increased carbon loss to respiration; (iii) elevated $\mathrm{CO}_{2}$ did not affect the allocations of $\mathrm{C}$ or $\mathrm{N}$ between the ear and stem during reproductive growth; and (iv) higher nighttime temperatures caused a significant decrease in the $\mathrm{C}$ and $\mathrm{N}$ allocation to the ears. They concluded that effect of the higher nighttime temperatures on the translocation of $\mathrm{C}$ and $\mathrm{N}$ to the ears will reduce the positive impact of increased $\mathrm{CO}_{2}$. The current mean air temperatures for the southern United States and many tropical regions during the rice grain filling phase in summer are nearly 26 to $27^{\circ} \mathrm{C}$ which are above the $25^{\circ} \mathrm{C}$ optimum and leads to the conclusion that further increases in air temperatures above current levels will reduce rice yield, by about $10 \%$ per $1^{\circ} \mathrm{C}$ rise. This is confirmed by an earlier study from Peng et al. (2004) who found that minimum temperatures were the most significant variable affecting rice yield.

There is evidence that exposure to cold temperatures are also detrimental in the pollination stage. Imin et al. (2004) observed that cold temperatures reduced the viability of the anthers and this has been significant enough to begin a screening program for tolerance to low temperatures (Sayfa et al., 2010). An analysis of the interactions of maximum and minimum temperatures with solar radiation was conducted using farmer-managed fields across 227 locations in tropical and subtropical Asia by Welch et al. (2010). Their observations revealed both temperature and solar radiation significantly impacted rice yields and increased minimum temperatures decreased yield while higher maximum temperatures increased yields because the maximum temperatures were not above the optimal threshold. They suggested moderate warming in the future would decrease yields and would increase in magnitude with increased warming because the effect of higher maximum temperatures would become negative (Welch et al., 2010).

\section{Sorghum}


In sorghum, the observed vegetative development has a base temperature $8^{\circ} \mathrm{C}$ with an optimum of $34^{\circ} \mathrm{C}$ (Alagarswamy and Ritchie, 1991), with an optimum temperature for preanthesis reproductive development of $31^{\circ} \mathrm{C}$ (Prasad et al., 2006a). The optimum temperature range for sorghum vegetative growth is between 26 and $34^{\circ} \mathrm{C}$ and for reproductive growth is 25 to $28^{\circ} \mathrm{C}$ (Maiti, 1996). Maximum dry matter production and grain yield has been observed at $27 / 22^{\circ} \mathrm{C}$ when compared to temperatures 3 or $6^{\circ} \mathrm{C}$ lower or 3 or $6^{\circ} \mathrm{C}$ warmer (Downs, 1972). Duration of grain filling reduces as temperature increases (Chowdhury and Wardlaw, 1978; Prasad et al., 2006a). Temperature increases above $36 / 26^{\circ} \mathrm{C}$ to $40 / 30^{\circ} \mathrm{C}$ (diurnal $\mathrm{max} / \mathrm{min}$ ) causes panicle emergence to be delayed by $20 \mathrm{~d}$ with no panicles formed at $44 / 34^{\circ} \mathrm{C}$ (Prasad et al., 2006a). Grain yield, HI, pollen viability, and percent seed-set were highest at $32 / 22^{\circ} \mathrm{C}$ and progressively reduced as temperature increased, falling to zero at $40 / 30^{\circ} \mathrm{C}$ (Prasad et al., 2006a). The highest vegetative biomass was observed at $40 / 30^{\circ} \mathrm{C}$ and photosynthetic rates were highest until temperatures reached $44 / 34^{\circ} \mathrm{C}$. Exposure to temperatures above $36 / 26^{\circ} \mathrm{C}$ caused a reduction in seed size. There are compensating effects when the temperatures are cooler than optimum for biomass/photosynthesis $\left(27 / 22^{\circ} \mathrm{C}\right)$ because yield loss from shorter filling period would be offset by increases in photosynthesis. Relating the yield response of sorghum to a shortening of filling period would cause a yield decline of $7.8 \%$ per $1^{\circ} \mathrm{C}$ temperature rise from 18.5 to $27.5^{\circ} \mathrm{C}$ (Chowdhury and Wardlaw, 1978). The temperature responses assembled by Chowdhury and Wardlaw (1978) are confirmed by estimates of an $8.4 \%$ decrease in global mean sorghum yield per $1^{\circ} \mathrm{C}$ increase in temperature as reported by Lobell and Field (2007).

\section{Cotton}

Cotton is considered to be adapted to high temperature environments; however, reproductive processes are adversely affected by elevated temperature (Reddy et al., 1991, 1995b, 2000, 2005). Since cotton is a tropical crop, leaf appearance rate has a relatively high base temperature of $14^{\circ} \mathrm{C}$ and a relatively high optimum temperature of $37^{\circ} \mathrm{C}$, with both leaf and vegetative growth tolerant of elevated temperatures (Reddy et al., 1999, 2005). In contrast, the reproductive progression (emergence to square, square to first flower) has a temperature optimum of 28 to $30^{\circ} \mathrm{C}$, along with a relatively high base temperature of $14^{\circ} \mathrm{C}$ (Reddy et al., $1997,1999)$. Maximum growth rate per boll occurs at 25 to $26^{\circ} \mathrm{C}$, and then declines at higher temperatures. Boll harvest index was highest at $28^{\circ} \mathrm{C}$ with further declines with increasing temperatures until zero boll harvest index occurs at 33 to $34^{\circ} \mathrm{C}$ (Reddy et al., 2005). Temperatures $<20^{\circ} \mathrm{C}$ caused the largest boll size and boll size declines progressively with temperature increases. As temperatures increase up to $35 / 27^{\circ} \mathrm{C}$ day/night temperature there was an initial compensation with increased boll number set; however, exposure to mean temperatures above $30^{\circ} \mathrm{C}$ caused percent boll set, boll number, boll filling period, rate of boll growth, boll size, and yield to decrease (Reddy et al., 2005). Exposure to shortterm air temperatures above $32^{\circ} \mathrm{C}$ decreases pollen viability and temperatures above $29^{\circ} \mathrm{C}$ reduces pollen tube elongation (Kakani et al., 2005) and progressively reduces successful boll formation to zero boll yield at $40 / 32^{\circ} \mathrm{C}$ day/night $\left(35^{\circ} \mathrm{C}\right.$ mean $)$ temperature (Reddy et al., 1992a, 1992b). Failure point temperatures of cotton are below those of soybean and peanut and similar to rice and sorghum. A well-defined cotton yield response to temperature does not exist and development of a quadratic (parabolic) yield response to temperature from the optimum of $25^{\circ} \mathrm{C}$ to the failure temperature of $35^{\circ} \mathrm{C}$ showed a $0.8^{\circ} \mathrm{C}$ increase from 26.7 to $27.5^{\circ} \mathrm{C}$ decreased yield by $3.5 \%$. A $1^{\circ} \mathrm{C}$ temperature increase on cotton yield was evaluated by Pettigrew (2008) who observed lint yield in two cultivars was reduced by $10 \%$ due to a reduction in boll mass and less seed in the bolls.

\section{Peanut}

Peanut is an important crop in the southern United States with a base temperature for peanut leaf appearance rate and onset of anthesis of 10 and $11^{\circ} \mathrm{C}$, respectively (Ong, 1986). Optimum temperatures for leaf appearance rate are above $30^{\circ} \mathrm{C}$, while the optimum for rate for vegetative development to anthesis is 29 to $33^{\circ} \mathrm{C}$ (Bolhuis and deGroot, 1959). Photosynthesis has a high temperature optimum of $36^{\circ} \mathrm{C}$. Cox (1979) found the optimum temperature for single pod growth rate and pod size was $24^{\circ} \mathrm{C}$, with slower growth rate and smaller pod size at higher temperatures. Williams et al. (1975) conducted a study across varying elevations to evaluate temperature effects on peanut, in which the observed peanut yield was highest at a mean temperature of $20^{\circ} \mathrm{C}\left(27 / 15^{\circ} \mathrm{C}\right.$ $\mathrm{max} / \mathrm{min}$ ) because these temperatures contributed to the longest life cycle and reproductive period. From sunlit, controlled-environment chambers, Prasad et al. (2003) concluded the optimum mean temperature for pod yield, seed yield, pod harvest index, and seed size was lower than $26^{\circ} \mathrm{C}$. Using quadratic projections to peak and minimum showed the optimum temperature was 23 to $24^{\circ} \mathrm{C}$, along with a failure point temperature of $40^{\circ} \mathrm{C}$ for zero yield and zero HI. Prasad et al. (2003) observed that pollen viability and percent seed-set began to fail at about $31^{\circ} \mathrm{C}$, reaching zero at about 39 to $40^{\circ} \mathrm{C}\left(44 / 34^{\circ} \mathrm{C}\right.$ treatment). An analysis of individual flowers showed the sensitive period to elevated temperature begins $6 \mathrm{~d}$ before opening of the flower and ends $1 \mathrm{~d}$ after, with greatest sensitivity on the day of flower opening (Prasad et al., 2001; Prasad et al., 2001). When exposed to bud temperature of $33^{\circ} \mathrm{C}$ there was a reduction in percent fruit-set with a linear decline to zero fruit-set at $43^{\circ} \mathrm{C}$ bud temperature (Prasad et al., 2001). Observations of genotypic differences to heat tolerance of peanut through pollen viability have been found (Craufurd et al., 2003). Since air temperature in the southern United States for the peanut growing season already averages $26.7^{\circ} \mathrm{C}$, temperature increases will further reduce seed yields $\left(4.1 \%\right.$ per $1^{\circ} \mathrm{C}$, or $3.3 \%$ for a $0.8^{\circ} \mathrm{C}$ rise in range of $26-27^{\circ} \mathrm{C}$ ) based on the relationship from Prasad et al. (2003).

\section{Dry Bean and Cowpea}

Red kidney bean is typical of many vegetable crops grown in cool regions of the United States. Red kidney bean was found to be quite sensitive to elevated temperature with highest seed yield at $28 / 18^{\circ} \mathrm{C}\left(23^{\circ} \mathrm{C}\right.$ mean) or lower (lower temperatures were not tested), and a linear decline to zero yield with temperature increases to $37 / 27^{\circ} \mathrm{C}\left(32^{\circ} \mathrm{C}\right.$ mean) (Prasad et al., 2002). In their study, pollen production per flower was reduced above $31 / 21^{\circ} \mathrm{C}$, pollen viability above $34 / 24^{\circ} \mathrm{C}$, and seed size above $31 / 21^{\circ} \mathrm{C}$. Laing et al. (1984) observed the highest bean yield occurred at $24^{\circ} \mathrm{C}$ and declined with higher temperatures. Gross and Kigel (1994) reported reduced fruit-set when flower buds were exposed to $32 / 27^{\circ} \mathrm{C}$ during the 6 to $12 \mathrm{~d}$ before anthesis and at anthesis due to nonviable pollen, failure of anther dehiscence, and reduced pollen tube growth. Jifon and Wolfe (2005) examined the 
interaction of heat stress and elevated $\mathrm{CO}_{2}$ on growth and yield of red kidney bean and found no $\mathrm{CO}_{2}$ benefit to pod yield at high temperatures when reproductive development was reduced.

Heat-induced decreases in seed and fruit-set in cowpea (Vigna unguiculata L.) are linked to nonviable pollen (Hall, 1992). Hall (1992) reported differences among genetic cultivars for heat tolerance of cowpea lines. Screening for temperature tolerance within bean cultivars has not been done explicitly, but the Mesoamerican lines are more tolerant of warm tropical locations than are the Andean lines which include the red kidney bean type (Sexton et al., 1994). Using the decline slope for temperature response based on the data of Prasad et al. (2002), bean yield is projected to decrease $7.2 \%$ per $1^{\circ} \mathrm{C}$ temperature rise.

\section{Synthesis of Temperature Effects}

The pollination phase of development is one of the most sensitive to episodic temperature increases. The synchrony of anthesis in each crop will dictate the crop sensitivity and ability to compensate to exposure to high temperatures and then exposure to improved weather during the remainder of the growth cycle, for example, maize has a highly compressed phase of anthesis, while rice and sorghum spikelets may achieve anthesis over a period of a week or more. Soybean, peanut, and cotton produce pollen over several weeks and thereby increase the potential success of reproduction. The period of exposure to high temperatures may not be isolated to a narrow window during reproduction as was found for peanut (and presumably other legumes) where the sensitivity to elevated temperature for a given flower, extends from $6 \mathrm{~d}$ before opening (pollen cell division and formation) up through the day of anthesis (Prasad et al., 2001). Exposure to hot temperatures and the resultant affect on flower fertility may occur whether these flowers are in their formative $6-\mathrm{d}$ phase or undergoing anthesis. Throughout the day, the first $6 \mathrm{~h}$ of the day appear to be more critical because pollen dehiscence, pollen tube growth, and fertilization are occurring during this period.

Observations have shown that rice and sorghum have a similar sensitivity of grain yield, seed $\mathrm{HI}$, pollen viability, and success in grain formation in which pollen viability and percent fertility is reduced by exposure to instantaneous hourly air temperature above $33^{\circ} \mathrm{C}$ and reaches zero at $40^{\circ} \mathrm{C}$ (Kim et al., 1996; Prasad et al., 2006a, 2006b). Exposure to diurnal $\mathrm{max} / \mathrm{min}$ day/night temperatures ranges of $40 / 30^{\circ} \mathrm{C}\left(35^{\circ} \mathrm{C}\right.$ mean $)$ produced no yield for rice and sorghum with the expectation of a similar response for maize. Higher temperatures will impact yields of all of the agronomic crops and exposure to episodic high temperatures will create stress on crop plants both in the vegetative and reproductive stages of development. Lobell (2007) evaluated the diurnal range of temperature on wheat, maize, and rice yields and observed yields to show a negative response to increased diurnal temperature ranges. He also observed a nonlinear response of yields to temperature because of the interaction of water and heat stress on hot days. Wassmann et al. (2009) reviewed the available literature on rice production and concluded that the reproductive period was the most sensitive to higher temperatures and we expect the same response in other cereal crops. The potential increase in the frequency of high temperature extremes during the growing season increases the likelihood for exposure of plants to high temperatures during the reproductive development stage. Two recent studies suggest that the increasing effect of temperature may have larger impacts than reported in previous studies. Kucharik and Serbin (2008) and Schlenker and Roberts (2009) evaluated crop yields for maize, soybean, and cotton to changes in temperature. Kucharik and Serbin (2008) conducted their analysis for Wisconsin data from 1976 to 2008 and reported for each degree of warming in the future corn yields could decrease by $13 \%$ and soybean by $16 \%$ without a change in precipitation. In their analysis, they found that the temperature effect would be offset by increases in precipitation. Schlenker and Roberts (2009) used the warming scenarios from climate change models and the same temperature relationships for maize, soybean, and cotton that were used in our paper and concluded that the increasing temperatures would negatively impact yields. They estimated under the slowest warming scenarios crop yields would decline 30 to $46 \%$ by the end of the century and under the rapid warming scenario, yields would decline 63 to $82 \%$ (Schlenker and Roberts, 2009). These results suggest that increasing attention be given to understanding the role of temperature changes on crop productivity to develop effective adaptive management strategies.

\section{Implications of Changes in Carbon Dioxide, Temperature, and Crop Water Use on Plant Productivity}

Rising $\mathrm{CO}_{2}$ from current concentrations to 380 to $450 \mu \mathrm{mol}$ $\mathrm{mol}^{-1}$ coupled with a $0.8^{\circ} \mathrm{C}$ increase in temperature and regional variation in soil water deficits and heavy rainfall events for next $30 \mathrm{yr}$ will have implications for the production of representative crops. The temperature responses detailed in the previous section show that our major agronomic crops could be expected to show signs of declining yields due to increased temperatures. When combined across temperature and $\mathrm{CO}_{2}$ responses for the individual species then the impacts of climate change can be assessed. We are in an era of uncharted responses and while analysis of the current literature can provide an assessment of crop grain yield response to temperature, often we have to rely on interpolation of plant response between optimum and failure temperatures for grain yield (as extracted from Table 2). These responses are relative to current mean temperatures during the reproductive phase in different regions (e.g., soybean and maize in Midwestern and Southern regions, as well as cotton, sorghum, and peanut [Arachis hypogaea L.] in Southern regions). Crop responsiveness of grain yield to $\mathrm{CO}_{2}$ is from Table 1, using Michaelis-Menten rectangular hyperbola interpolation with value of 1.0 at $350 \mu \mathrm{mol} \mathrm{mol}{ }^{-1}$, the enhancement ratio set at $700 \mu \mathrm{mol} \mathrm{mol}{ }^{-1}$ and a compensation $\mathrm{CO}_{2}$ concentration consistent with $\mathrm{C}_{3}$ or $\mathrm{C}_{4}$ species at $30^{\circ} \mathrm{C}$. Using this generalized shape, the response for 380 to $440 \mu \mathrm{mol}$ $\mathrm{mol}^{-1} \mathrm{CO}_{2}$ was $1.0 \%$ for $\mathrm{C}_{4}$ and 6.1 to $9.4 \%$ for $\mathrm{C}_{3}$ species, except for cotton which showed $9.4 \%$ response. With adequate water, maize in the Midwest had the net yield response of $-1.5 \%$, by combining the $-2.5 \%$ from $0.8^{\circ} \mathrm{C}$ rise and $+1.0 \%$ from $\mathrm{CO}_{2}$ of 380 to $440 \mu \mathrm{mol} \mathrm{mol}^{-1}$ (Table 1). Yield response of maize in the South is likely more negative because of the temperature effect on growth and reproduction. Although maize is widely grown in the United States and produces the largest amount of grain, the certainty of temperature and $\mathrm{CO}_{2}$ effects on maize yields is limited by minimal studies and contradictory reports on temperature and $\mathrm{CO}_{2}$ responses. Soybean, assuming sufficient soil water availability in the Midwest, shows a net yield response of $+9.1 \%$, when we add the $+1.7 \%$ from $0.8^{\circ} \mathrm{C}$ rise above current $22.5^{\circ} \mathrm{C}$ mean and 
$+7.4 \%$ from rising $\mathrm{CO}_{2}$. A different picture emerges for soybean in the South, because the temperature increase will be detrimental, $-2.4 \%$, with $0.8^{\circ} \mathrm{C}$ temperature increment above the current $26.7^{\circ} \mathrm{C}$, with the same $\mathrm{CO}_{2}$ effect, gives a net yield response of $+5.0 \%$, even when water supplies are sufficient. Assuming no change in water availability, the net wheat yield response would be $+2.4 \%$ derived from a projected $-4.4 \%$ with $0.8^{\circ} \mathrm{C}$ rise and $+6.8 \%$ increase from rising $\mathrm{CO}_{2}$. Rice grown in the southern United States shows a net yield response of $-1.6 \%$, derived from the temperature effect of $-8.0 \%$ projected from $0.8^{\circ} \mathrm{C}$ rise and $+6.4 \%$ from $\mathrm{CO}_{2}$ increases. Projected yield impacts for peanut show a net response of $+3.4 \%$, based on adding $-3.3 \%$ from $0.8^{\circ} \mathrm{C}$ rise and $+6.7 \%$ from $\mathrm{CO}_{2}$ changes. Cotton yields are projected to have a net yield response of $+5.7 \%$, based on the additive effects from $-3.5 \%$ from $0.8^{\circ} \mathrm{C}$ rise and $+9.2 \%$ from increased $\mathrm{CO}_{2}$. Sorghum yield response is less certain; however, yield reduction anticipated from shortened filling period provides a net yield decrease of $5.2 \%$. Bean yield response is also less certain, with net yield effect of $+0.3 \%$, derived from combining a $-5.8 \%$ response to $0.8^{\circ} \mathrm{C}$ rise and $+6.1 \%$ from increased $\mathrm{CO}_{2}$ (Table 3 ).

The increased potential for water deficits will also impact crop yields and to assess these impacts under climate change we can begin with the Table 3 responses to temperature and $\mathrm{CO}_{2}$ for the water-sufficient cases. The underlying assumption is that yields will increase by the same extent caused by the increased $\mathrm{CO}_{2}$ causing a reduction in ET. Estimates of future yields derived from simulations with CROPGRO-Soybean incorporating an energy balance option and stomatal feedback derived from $\mathrm{CO}_{2}$ enrichment (350-700 $\mu \mathrm{mol} \mathrm{mol}{ }^{-1}$, but with no temperature increase) produced a $44 \%$ yield increase for water-stressed crops compared to fully irrigated (32\%). The yield increment was nearly proportional to the decrease in simulated transpiration (11-16\%). Based on this assumption, the 380 to $440 \mu \mathrm{mol} \mathrm{mol}{ }^{-1} \mathrm{CO}_{2}$ increment would further increase yield of $\mathrm{C}_{3}$ crops (soybean, rice, wheat, and cotton) by an additional 1.4 to $2.1 \%$ (incremental reduction in ET from $\mathrm{CO}_{2}$ in Table 1). However, the projected $0.8^{\circ} \mathrm{C}$ increases ET by $1.2 \%$, nearly negating the effect of $\mathrm{CO}_{2}$ on reducing ET. While it is difficult to predict the exact scenarios of precipitation changes under future climate change, the impact of both excess and deficit amounts of soil water on all crops will be substantial and cannot be ignored as part of the potential impacts on food security.

\section{CLIMATE CHANGE ON GRAIN QUALITY}

One of the emerging challenges will be to understand and quantify the impacts of changing climate on grain quality. Kimball et al. (2001) observed an interaction between $\mathrm{N}$ status in plants and grain quality in wheat and showed that low $\mathrm{N}$ reduced grain quality which was further exaggerated by high $\mathrm{CO}_{2}$ concentrations. Conroy and Hocking (1993) showed a steady decline in grain protein from 1967 to 1990 in wheat grown in Australia. They suggested not all of this change can be specifically linked to rising $\mathrm{CO}_{2}$, but $\mathrm{CO}_{2}$ increases may be contributing to this decline. These observations suggest nutrient status in plants interacts with changing $\mathrm{CO}_{2}$ concentrations although there is no specific statement on the impacts of rising $\mathrm{CO}_{2}$ on $\mathrm{N}$ requirements in crops, other than the general concept that greater growth and yields require greater $\mathrm{N}$ supply. Erbs et al. (2010) completed a study on $\mathrm{CO}_{2}$ enrichment and $\mathrm{N}$ management on grain quality in wheat and barley (Hordeum vulgare L.) and found that increasing $\mathrm{CO}_{2}$ to $550 \mu \mathrm{mol} \mathrm{mol}^{-1}$ with two rates of $\mathrm{N}$, adequate and half of the $\mathrm{N}$, affected crude protein, starch, total and soluble $\mathrm{B}$-amylase, and single kernel hardiness. They observed that increasing $\mathrm{CO}_{2}$ reduced crude protein by 4 to $13 \%$ in wheat and 11 to $13 \%$ in barley but increased starch by $4 \%$ when half-rate $\mathrm{N}$ was applied. They concluded that nutritional and processing quality of flour will be diminished for cereal grown under elevated $\mathrm{CO}_{2}$ and low $\mathrm{N}$ fertilization. This study highlights the need to increase our understanding of these interactions because they are not well-defined and understanding these interactions would provide insights into the interactions of genetic by management interactions. In cultivated systems it is apparent that greater attention will have to be given to $\mathrm{N}$ management in cultivated crops with climate change to increase production efficiency and to maintain both yields and protein concentration in grains.

\section{CLIMATE IMPACTS ON WEEDS Carbon Dioxide}

Among plant species, weeds, rather than crops, across several studies show the strongest relative response to rising $\mathrm{CO}_{2}$ (Ziska, 2004). Even though individual plants of rice or wheat respond positively to rising $\mathrm{CO}_{2}$, the increased response of weedy species to $\mathrm{CO}_{2}$ create the potential for increased competition and increased crop production losses (Ziska, 2000, 2003a, 2003b; Ziska et al., 2005). Based on continuation of this phenomenon, rising $\mathrm{CO}_{2}$ could lead to yield reductions in agricultural systems where weed control is not practiced or sufficient.

\section{Climatic Factors}

Although moisture is a recognized factor in weed seed establishment and final plant size, little is known about interactions between altered precipitation and weed biology. At the whole plant level, changes in precipitation and water availability are likely to affect weeds of agricultural importance in a number of ways. Several annual weeds, from cheatgrass (Bromus tectorum) to yellow star thistle (Centaurea solstitialis) depend on moisture for seed germination. More moisture is associated with overwintering and increased seed production for both species (Patterson, 1995a). However, both species are drought adapted, cheatgrass being able to complete its life-cycle quickly on available moisture, whereas star thistle can develop a deeper root system than many native plants. Timing of precipitation may also be critical. For example, greater spring-time moisture associated with El Niño events may expand cheatgrass habitat (Bradley and Mustard, 2005). Overall, changes in the timing and amount of precipitation are likely to alter several aspects of weeds including germination, plant size, seed production, and the distribution of water borne seeds. At the community level it is also probable that precipitation extremes will alter competition between invasive weeds and crops with subsequent effects on productivity (Patterson, 1995b).

Along with precipitation, temperature is a primary abiotic variable that affects invasive weed biology. The probable impact of rising temperatures on the expansion of invasive weeds into higher latitudes is of particular concern. Many of the worst invasives for warm season crops in the southern United States originated in tropical or warm temperature areas; consequently, northward expansion of these invasives may accelerate with warming (Patterson, 1993). For example, itchgrass (Rottboelliia cochinchinensis), an invasive weed associated with significant yield reductions in 
sugarcane for Louisiana (Lencse and Griffin, 1991), is also highly competitive in corn, cotton, soybean, grain sorghum, and rice systems (e.g., Lejeune et al., 1994). The response of this species to a $3^{\circ} \mathrm{C}$ increase in average temperature stimulated biomass by $88 \%$ and leaf area by $68 \%$ (Patterson et al., 1979), projecting increases in growth for the middle Atlantic states (Patterson et al., 1999). Northward migration of other invasive weeds, such as cogongrass (Imperata cylindrica) and witchweed (Striga asiatica), is also anticipated (Patterson, 1995a). Conversely, additional warming could also restrict the southern range of other invasive weeds, for example, wild proso millet (Panicum miliaceum) or Canada thistle (Ziska and Runion, 2007).

One of the most interesting forecasts regarding global warming and an invasive weed was made almost two decades ago in regard to Northward migration of kudzu (Pueraria lobata), an ubiquitous invasive of the southeastern United States. Sasek and Strain (1990) observed that the latitudinal distribution at that time was limited to southern regions by low winter temperatures of $-15^{\circ} \mathrm{C}$ (Fig. 7 in Sasek and Strain, 1990). More recently, Wolfe et al. (2008) projected expansion of the habitable range of kudzu into the northeastern United States during the 21 st century based on climate model projections of the northward migration of the $-15^{\circ} \mathrm{C}$ isocline.

\section{Mechanisms}

Overall, the projected warming may be exceeding maximum rates of plant migration observed in postglacial periods (Malcolm et al., 2002), resulting in preferential selection for the most mobile plant species. Several characteristics associated with long-distance dispersal are commonly found among agronomic weeds (Rejmanek, 1996), suggesting that they will be among the fastest to migrate with increasing temperatures (Dukes and Mooney, 2000).

The basis for the enhanced response of weedy species within agroecosystems is not entirely evident. In some instances, the physiological characteristics of crop or a weed being a $\mathrm{C}_{3}$ or $\mathrm{C}_{4}$ plant will determine its response to $\mathrm{CO}_{2}$ and its competitive abilities (Table 1 from Ziska and Runion, 2007). However, many of the problem weeds within a given crop are the wild (uncultivated) plants from the same genus or species (e.g., rice and wild rice, oat and wild oat, sorghum and shattercane) and will most likely exhibit the same photosynthetic pathway. An alternate suggestion is the greater range of responses observed for weeds with increasing atmospheric $\mathrm{CO}_{2}$ is due to their greater genetic diversity compared to crops and with the greater gene pool there is a greater likelihood for a species to respond to a resource change (Treharne, 1989). Still, the degree of diversity may be of potential benefit at a time of climatic uncertainty. For example, identifying specific genetic, morphological, or phenotypic traits within wild lines, and the appropriate techniques for transferring these traits to cultivated lines, could, over time, be the focus of future work in any systematic effort to improve cultivated crop yields in response to rising atmospheric $\mathrm{CO}_{2}$ or to climatic extremes (Ziska and McClung, 2008).

\section{Management}

An increasing number of studies demonstrate a decline in pesticide efficacy with rising $\mathrm{CO}_{2}$ (reviewed by Archambault, 2007). The basis for this observed decline in efficacy is unclear; however, rising $\mathrm{CO}_{2}$ could reduce pesticide absorption into leaves by decreasing the number or aperture of stomata or by changing leaf thickness or size. Changes in transpiration induced by $\mathrm{CO}_{2}$ could limit uptake of soil-applied pesticides. To achieve effective weed control, timing of application may need to be adjusted if elevated $\mathrm{CO}_{2}$ decreases the length of the weed seedling stage (i.e., the time of greatest chemical susceptibility). In spite of these climate effects on weeds, the overall assumption is that chemical control of weeds will be possible, either through additional sprayings, or increased herbicide concentrations; however, this would alter the environmental and economic costs of pesticide usage. Although there are other weed control methods (e.g., biological, mechanical, cultural), climatic and $\mathrm{CO}_{2}$ changes and the overall effects of precipitation, temperature, wind, etc. may make nonchemical control less efficacious (Patterson, 1995a).

\section{CLIMATE IMPACTS ON INSECTS AND PATHOGENS}

Agroecosystems are complex mixtures of plants (economic and weeds) and insects and diseases. There are the direct impacts of climate change on the economic crop as well as weeds (previous section), insects, and diseases. A holistic understanding of the $\mathrm{CO}_{2}$ and climate changes to beneficial and harmful insects, microbes, and other organisms in the environment is urgently needed to develop adaptive management of agroecosystems under climate change. Documented changes in spring arrival and/or geographic range of many insect and animal species due to climate change have been observed from studies in western Europe and other regions (Montaigne, 2004; Goho, 2004; Walther, 2002). Coakley et al. (1999) reported that temperature was the single most important factor affecting insect ecology, epidemiology, generations per growing season, and insect distribution, while plant pathogens are highly responsive to humidity and rainfall, along with temperature.

Greater insecticide use in warmer, more southern regions of the United States compared to cooler higher latitude regions has been observed. Comparing the frequency of pesticide sprays for control of lepidopteran insect pests in sweet corn currently ranges from 15 to 32 applications per year in Florida (Aerts et al., 1999), to four to eight applications in Delaware (Whalen et al., 2007), and zero to five applications per year in New York (Stivers, 1999) because of the temperature effects on insect populations. Populations of insect species, such as flea beetles (Chaetocnema pulicaria), are currently marginally overwintering in high latitude regions. This vector for bacterial Stewart's Wilt (Erwinia sterwartii), an economically important corn pathogen, will increase because of the warmer winters (Wolfe et al., 2008; Harrington et al., 2001).

Leaf and root pathogens will be favored by increases in humidity and frequency of heavy rainfall events projected for many parts of the United States (Coakley et al., 1999). Conversely, short- to medium-term droughts will decrease the duration of leaf wetness and reduce some forms of pathogen attack on leaves; however, such droughts will also negatively impact crop yields from lack of available soil water.

Plant-insect interactions may be affected by increasing $\mathrm{CO}_{2}$ concentrations and this would have implications for insect management. Higher $\mathrm{C} / \mathrm{N}$ ratio of leaves observed in plants grown at high $\mathrm{CO}_{2}$ (Wolfe, 1994) will require increased insect feeding to meet $\mathrm{N}$ (protein) requirements (Coviella and Trumble, 1999). 
Conversely, slower insect development on high $\mathrm{CO}_{2}$-grown plants lengthens the insect life stages vulnerable to attack by parasitoids (Coviella and Trumble, 1999). An observation from a FACE study revealed early season soybeans grown at elevated $\mathrm{CO}_{2}$ exhibited $57 \%$ more insect damage, presumably due to increases in simple sugars in leaves (Hamilton et al., 2005).

\section{IMPLICATIONS}

Climate change, either as increasing trends in temperature, $\mathrm{CO}_{2}$, precipitation (decreasing as well as increasing), and/or $\mathrm{O}_{3}$, will have impacts on agricultural systems. Production of annual and perennial crops will be affected by changes in the absolute values of these climatic variables and/or increased variation. Episodic temperature changes exceeding the thresholds during the pollination stage of development could be quite damaging to crop production because of the sensitivity of crop plants to temperature extremes during this growth stage. These changes coupled with variable precipitation that places the plant under conditions of water stress would exacerbate the temperature effects. Warmer temperatures during the night, especially during the reproductive period, will reduce fruit or grain size because the rapid rate of development and increased respiration rates. A recent analysis by Ko et al. (2010), using the CERES-Wheat 4.0 module in the RZWQM2 model, evaluated the interactions of increasing $\mathrm{CO}_{2}$ obtained from a FACE experiment along with temperature, water, and $\mathrm{N}$. They found the effects of water and $\mathrm{N}$ were greater than $\mathrm{CO}_{2}$ effects on biomass and yield and that temperature effects offset the $\mathrm{CO}_{2}$ effects. These results further confirm the concept that there are counterbalancing effects from different climate variables and that development of adaptation or mitigation strategies will have to account for the combined effects of climate variables on crop growth, development, and yield. In an effort to examine potential solutions to low yields in sub-Saharan Africa, Laux et al. (2010) evaluated planting dates under climate change scenarios to evaluate the effect of increasing $\mathrm{CO}_{2}$ and higher temperature on groundnut (peanut) and maize. They found the positive effect of $\mathrm{CO}_{2}$ would offset the temperature response in the next 10 to $20 \mathrm{yr}$ but would be overcome by higher temperatures by 2080 . Changing planting dates were beneficial for the driest locations because of the more effective use of precipitation and avoidance of high temperature stresses. Both of these types of analyses will have to be conducted to evaluate potential adaptation strategies for all cropping regions.

Increases in $\mathrm{CO}_{2}$ concentrations offer positive impacts to plant growth and increased WUE. However, these positive impacts may not fully mitigate crop losses associated with heat stress, increases in evaporative demand, and/or decreases in water availability in some regions. The episodic variation in extremes may become the larger impact on plant growth and yield. To counteract these effects will require management systems that offer the largest degree of resilience to climatic stresses as possible. This will include the development of management systems for rainfed environments that can store the maximum amount of water in the soil profile and reduce water stress on the plant during critical growth periods.

\section{CHALLENGES TO AGRONOMISTS}

Increasing food security with the challenge of increasing climate change will require that the agricultural systems be viewed from a holistic perspective to understand the implications of the interactions of changing temperature, $\mathrm{CO}_{2}$, and precipitation on the growth and development processes. The impacts of rising temperatures on reducing grain yield in crops can produce serious consequences in terms of stability of grain production, and the impacts of the high temperatures on grain set and pollination may not be offset by beneficial growth stimulations due to the direct effects of the rising $\mathrm{CO}_{2}$ levels. These changes coupled with the increasing variability in precipitation offer a challenge to agronomists to begin to quantify how cropping systems can be made more resilient to stress. Coupling physiological responses with genetic traits provides an opportunity to create more robust cropping systems that can cope with the changing climate. These evaluations of the interaction of genetics with the environment, especially the potential climate change scenarios, will require an understanding of how these variables interact during the growth cycle of crops. The review by Wassmann et al. (2009) provides an overview of the possible adapation strategies for rice based on response to climate change. They concluded that germplasm improvement and natural resource management have proven to reduce susceptibilty of agricultural systems to stress and the maximum benefit will be realized when crop technology options are combined with advanced climatology tools. There will be changes in the distribution of crop plants with climate change and those changes require a lengthy treatise to discuss in detail and this review has only focused on the potential impacts to the current cropping systems.

Changes in the weed, insect, and disease dynamics under the changing climate will further exaggerate the stresses on plants. The expanded range of pests and potentially more favorable conditions creates a situation in which the resilience of cropping systems will have to account for the interactions of pest populations along with physiological changes. This also calls for more coordination among regional integrated pest management (IPM) programs to monitor pest range shifts and develop an early warning system for farmers. There is no lack of potential challenges to our crop production systems presented by the changes in climate. This creates an opportunity for agronomists to form partnerships to address these challenges and create a future for humankind that ensures an adequate food supply through increased food security.

\section{REFERENCES}

Adams, C.D., S. Spitzer, and R.M. Cowan. 1996. Biodegradation of nonionic surfactants and effects of oxidative pretreatment. J. Environ. Eng. 122:477-483.

Adams, R.M., C. Rosenzweig, R.M. Peart, J.T. Richie, B.A. McCarl, J.D. Glyer, R.B. Curry, J.W. Jones, K.J. Boote, and L.H. Allen, Jr. 1990. Global climate change and US agriculture. Nature (London) 345:219-224.

Aerts, M., P. Cockrell, G. Nuessly, R. Raid, T. Schueneman, and D. Seal. 1999. Crop profile for corn (sweet) in Florida. Available at http://www.impcenters.org/CropProfiles/docs/FLcorn-sweet.html (verified 15 Dec. 2010).

Ainsworth, E.A. 2008. Rice production in a changing climate: A meta-analysis of responses to elevated carbon dioxide and elevated ozone concentration. Glob. Change Biol. 14:1642-1650.

Ainsworth, E.A., P.A. Davey, C.J. Bernacchi, O.C. Dermody, E.A. Heaton, D.J Moore, P.B. Morgan, S.A. Naidu, H.-S. Yoo Ra, X.-G. Zhu, P.S. Curtis, and S.P. Long. 2002. A meta-analysis of elevated $\mathrm{CO}_{2}$ effects on soybean (Glycine max) physiology, growth and yield. Glob. Change Biol. 8:695-709.

Ainsworth, E.A., and S.P. Long. 2005. What have we learned from 15 years of free-air $\mathrm{CO}_{2}$ enrichment (FACE)? A meta-analytic review of the responses of photosynthesis, canopy properties and plant production to rising $\mathrm{CO}_{2}$. New Phytol. 165:351-372. 
Ainsworth, E.A., and A. Rogers. 2007. The response of photosynthesis and stomatal conductance to rising $\mathrm{CO}_{2}$ : Mechanisms and environmental interactions. Plant Cell Environ. 30:258-270.

Alagarswamy, G., and J.T. Ritchie. 1991. Phasic development in CERES-sorghum model. p. 143-152. In T. Hodges (ed.) Predicting crop phenology. CRC Press, Boca Raton, FL.

Allen, L.H., Jr. 1990. Plant responses to rising carbon dioxide and potential interactions with air pollutants. J. Environ. Qual. 19:15-34.

Allen, L.H., Jr., and K.J. Boote. 2000. Crop ecosystem responses to climatic change: Soybean. p. 133-160. In K.R. Reddy and H.F. Hodges (ed.) Climate change and global crop productivity. CAB Int., New York.

Allen, L.H., Jr., D. Pan, K.J. Boote, N.B. Pickering, and J.W. Jones. 2003. Carbon dioxide and temperature effects on evapotranspiration and water-use efficiency of soybean. Agron. J. 95:1071-1081.

Allen, R.G., F.N. Gichuki, and C. Rosenzweig. 1991. $\mathrm{CO}_{2}$-induced climatic changes and irrigation-water requirements. J. Water Resour. Plann. Manage. 117:157-178.

Allen, R.G., I.A. Walter, R.L. Elliot, T.A. Howell, D. Itenfisu, M.E. Jensen, and R.L. Snyder. 2005. The ASCE standardized reference evapotranspiration equation. Am. Soc. of Civil Eng., Reston, VA.

Alocilja, E.C., and J.T. Ritchie. 1991. A model for the phenology of rice. p. 181-189. In T. Hodges (ed.) Predicting crop phenology. CRC Press, Boca Raton, FL.

Amthor, J.S. 2001. Effects of atmospheric $\mathrm{CO}_{2}$ concentration on wheat yield: Review of results from experiments using various approaches to control $\mathrm{CO}_{2}$ concentration. Field Crops Res. 73:1-34.

Andre, M., and H. du Cloux. 1993. Interaction of $\mathrm{CO}_{2}$ enrichment and water limitations on photosynthesis and water use efficiency in wheat. Plant Physiol. Biochem. 31:103-112.

Archambault, D.J. 2007. Efficacy of herbicides under elevated temperature and $\mathrm{CO}_{2}$. p. 262-279. In P.C.D. Newton et al. (ed.) Agroecosystems in a changing climate. CRC Press, Boston, MA.

Ashmore, M.R. 2002. Effects of oxidants at the whole plant and community level. p. 89-118. In J.N.B. Bell and M. Treshow (ed.) Air pollution and plant life. John Wiley, Chichester, NH.

Ashmore, M.R. 2005. Assessing the future global impacts of ozone on vegetation. Plant Cell Environ. 28:949-964.

Badu-Apraku, B., R.B. Hunter, and M. Tollenaar. 1983. Effect of temperature during grain filling on whole plant and grain yield in maize (Zea mays L.). Can. J. Plant Sci. 63:357-363.

Baker, J.T., and L.H. Allen, Jr. 1993a. Contrasting crop species responses to $\mathrm{CO}_{2}$ and temperature: Rice, soybean, and citrus. Vegetatio 104/105:239-260.

Baker, J.T., and L.H. Allen, Jr. 1993b. Effects of $\mathrm{CO}_{2}$ and temperature on rice: A summary of five growing seasons. J. Agric. Meteorol. 48:575-582.

Baker, J.T., L.H. Allen, Jr., and K.J. Boote. 1989. Response of soybean to air temperature and carbon dioxide concentration. Crop Sci. 29:98-105.

Baker, J.T., K.J. Boote, and L.H. Allen, Jr. 1995. Potential climate change effects on rice: Carbon dioxide and temperature. p. 31-47. In C. Rosenzweig et al. (ed.) Climate change and agriculture: Analysis of potential international impacts. ASA Spec. Publ. 59. ASA, CSSA, and SSSA, Madison, WI.

Balaguer, L., J.D. Barnes, A. Panicucci, and A.M. Borland. 1995. Production and utilization of assimilates in wheat (Triticum aestivum L.) leaves exposed to elevated $\mathrm{O}_{3}$ and/or $\mathrm{CO}_{2}$. New Phytol. 129:557-568.

Barnes, J.D., J.H. Ollerenshaw, and C.P. Whitfield. 1995. Effects of elevated $\mathrm{CO}_{2}$ and/or $\mathrm{O}_{3}$ on growth, development and physiology of wheat (Triticum aestivum L.). Glob. Change Biol. 1:101-114.

Ben-Asher, J., A. Garcia, Y. Garcia, and G. Hoogenboom. 2008. Effect of high temperature on photosynthesis and transpiration of sweet corn (Zea mays L. var. rugosa). Photosynthesis 46:595-603.

Bender, J., U. Hertstein, and C. Black. 1999. Growth and yield responses of spring wheat to increasing carbon dioxide, ozone and physiological stresses: A statistical analysis of 'ESPACE-wheat' results. Eur. J. Agron. 10:185-195.

Bernacchi, C.J., B.A. Kimball, D.R. Quarles, S.P. Long, and D.R. Ort. 2007. Decreases in stomatal conductance of soybean under open-air elevation of $\mathrm{CO}_{2}$ are closely coupled with decreases in ecosystem evapotranspiration. Plant Physiol. 143:134-144.

Bernacchi, C.J., A.D.B. Leakey, L.E. Heady, P.B. Morgan, F.G. Dohleman, J.M. McGrath, K.M. Gillespie, V.E. Wittig, A. Rogers, S.P. Long, and D.R. Ort. 2006. Hourly and seasonal variation in photosynthesis and stomatal conductance of soybean grown at future $\mathrm{CO}_{2}$ and ozone concentrations for 3 years under fully open-air field conditions. Plant Cell Environ. 29:2077-2090.

Black, V.J., C.R. Black, J.A. Roberts, and C.A. Stewart. 2000. Impact of ozone on the reproductive development of plants. New Phytol. 147:421-447.
Bolhuis, C.G., and W. deGroot. 1959. Observations on the effect of varying temperature on the flowering and fruit set in three varieties of groundnut. Neth. J. Agric. Sci. 7:317-326.

Boote, K.J., L.H. Allen, P.V.V. Prasad, J.T. Baker, R.W. Gesch, A.M. Snyder, D. Pan, and J.M.G. Thomas. 2005. Elevated temperature and $\mathrm{CO}_{2}$ impacts on pollination, reproductive growth, and yield of several globally important crops. J. Agric. Meteorol. 60:469-474.

Boote, K.J., J.W. Jones, and G. Hoogenboom. 1998. Simulation of crop growth: CROPGRO Model. p. 651-692. In R.M. Peart and R.B. Curry (ed.) Agricultural systems modeling and simulation. Marcel Dekker, New York.

Boote, K.J., N.B. Pickering, and L.H. Allen, Jr. 1997. Plant modeling: Advances and gaps in our capability to project future crop growth and yield in response to global climate change. p. 179-228. In L.H. Allen et al. (ed.) Advances in carbon dioxide effects research. ASA Spec. Publ. 61. ASA, CSSA, and SSSA, Madison, WI.

Bradley, B.A., and J.F. Mustard. 2005. Identifying land cover variability distinct from land cover change: Cheatgrass in the great basin. Remote Sens. Environ. 94:204-213.

Brown, P.W. 1987. User's guide to the Arizona meteorological network. City of Phoenix. Water Conserv. and Resource Div., and Arizona Coop. Ext., Phoenix, AZ .

Cheng, W., H. Sakai, K. Yagi, and T. Hasegawa. 2010. Combined effects of elevated $\mathrm{CO}_{2}$ and high night temperature con carbon assimilation, nitrogen absorption, and the allocations of $\mathrm{C}$ and $\mathrm{N}$ by rice (Oryza sativa L.). Agric. For. Meteorol. 150:1174-1181.

Chowdhury, S.I.C., and I.F. Wardlaw. 1978. The effect of temperature on kernel development in cereals. Aust. J. Agric. Res. 29:205-233.

Coakley, S.M., H. Scherm, and S. Chakraborty. 1999. Climate change and plant disease management. Annu. Rev. Phytopathol. 37:399-426.

Commuri, P.D., and R.D. Jones. 2001. High temperatures during endosperm cell division in maize: A genotypic comparison under in vitro and field conditions. Crop Sci. 41:1122-1130.

Conroy, J., and P. Hocking. 1993. Nitrogen nutrition of C-3 plants at elevated atmospheric $\mathrm{CO}_{2}$ concentrations. Physiol. Plant. 89:570-576.

Coviella, C., and J. Trumble. 1999. Effects of elevated atmospheric carbon dioxide on insect-plant interactions. Conserv. Biol. 13:700-712.

Cox, F.R. 1979. Effect of temperature treatment on peanut vegetative and fruit growth. Peanut Sci. 6:14-17.

Crafts-Brandner, S.J., and M.E. Salvucci. 2002. Sensitivity of photosynthesis in a C-4 plant, maize, to heat stress. Plant Physiol. 129:1773-1780.

Craufurd, P.Q., P.V.V. Prasad, and V.G. Kakani. 2003. Heat tolerance in groundnut. Field Crops Res. 80:63-77.

Dentener, F., D. Stevenson, J. Cofala, R. Mechler, M. Amann, P. Bergamaschi, F. Raes, and R. Derwent. 2005. The impact of air pollutant and methane emission controls on tropospheric ozone and radiative forcing: CTM calculations for the period 1990-2030. Atmos. Chem. Phys. 5:1731-1755.

Dermody, O., S.P. Long, and E.H. DeLucia. 2006. How does elevated $\mathrm{CO}_{2}$ or ozone affect the leaf-area index of soybean when applied independently? New Phytologist 169:145-155.

Dessler, A., and S.C. Sherwood. 2009. A matter of humidity. Science (Washington, DC) 323:1020-1021.

Donnelly, A., M.B. Jones, J.I. Burke, and B. Schnieders. 2000. Elevated $\mathrm{CO}_{2}$ provides protection from $\mathrm{O}_{3}$ induced photosynthetic damage and chlorophyll loss in flag leaves of spring wheat (Triticum aestivum L., cv. 'Minaret'). Agric. Ecosyst. Environ. 80:159-168.

Downs, R.W. 1972. Effect of temperature on the phenology and grain yield of Sorghum bicolor. Aust. J. Agric. Res. 23:585-594.

Dukes, J.S., and H.A. Mooney. 2000. Does global change increase the success of biological invaders? Trends Ecol. Evol. 14:135-139.

Dupuis, L., and C. Dumas. 1990. Influence of temperature stress on in vitro fertilization and heat shock protein synthesis in maize (Zea mays L.) reproductive systems. Plant Physiol. 94:665-670.

Edwards, G.E., and N.R. Baker. 1993. Can $\mathrm{CO}_{2}$ assimilation in maize be predicted accurately from chlorophyll fluorescence analysis. Photosynth. Res. 37:89-102.

Egli, D.B., and I.F. Wardlaw. 1980. Temperature response of seed growth characteristics of soybean. Agron. J. 72:560-564.

Elagoz, V., and W.J. Manning. 2005. Responses of sensitive and tolerant bush beans (Phaseolus vulgaris L.) to ozone in open-top chambers are influenced by phenotypic differences, morphological characteristics, and the chamber environment. Environ. Pollut. 136:371-383.

Erbs, M., R. Manderscheid, G. Jansen, S. Seddig, A. Pacholski, and H.-J. Weigel. 2010. Effects of free-air $\mathrm{CO}_{2}$ enrichment and nitrogen supply on grain quality parameters of wheat and barley grown in a crop rotation. Agric. Ecosyst. Environ. 136:59-68. 
Field, C.B., R.B. Jackson, and H.A. Mooney. 1995. Stomatal responses to increased $\mathrm{CO}_{2}$ : Implications from the plant to the global scale. Plant Cell Environ. 18:1214-1225.

Finnan, J.M., A. Donnelly, J.L. Burke, and M.B. Jones. 2002. The effects of elevated concentrations of carbon dioxide and ozone on potato (Solanum tuberosum L.) yield. Agric. Ecosyst. Environ. 88:11-22.

Fonseca, A.E., and M.E. Westgate. 2005. Relationship between desiccation and viability of maize pollen. Field Crops Res. 94:114-125.

Goho, A. 2004. Gardeners anticipate climate change. Am. Gardener 83:36-41.

Goudriaan, J., and M.H. Unsworth. 1990. Implications of increasing carbon dioxide and climate change for agricultural productivity and water resources. p. 111-130. In B.A. Kimball et al. (ed.) Impact of carbon dioxide, trace gases, and climate change on global agriculture. ASA Spec. Publ. 53. ASA, Madison, WI.

Grimm, S.S., J.W. Jones, K.J. Boote, and D.C. Herzog. 1994. Modeling the occurrence of reproductive stages after flowering for four soybean cultivars. Agron. J. 86:31-38.

Grimm, S.S.,J.W. Jones, K.J. Boote, and J.D. Hesketh. 1993. Parameter estimation for predicting flowering date of soybean cultivars. Crop Sci. 33:137-144.

Gross, Y., and J. Kigel. 1994. Differential sensitivity to high temperature of stages in the reproduction development of common beans (Phaseolus vulgaris L.). Field Crops Res. 36:201-212.

Hall, A.E. 1992. Breeding for heat tolerance. p. 129-168. In J. Janick (ed.) Plant breeding reviewers. Vol. 10. John Wiley \& Sons, New York.

Hamilton, J.G., O. Dermody, M. Aldea, A.R. Zangerl, A. Rogers, M.R. Berenbaum, and E.H. DeLucia. 2005. Anthropogenic changes in tropospheric composition increase susceptibility of soybean to insect herbivory. Environ. Entomol. 34:479-485.

Harrington, R., R. Fleming, and I.P. Woiwood. 2001. Climate change impacts on insect management and conservation in temperate regions: Can they be predicted? Agric. For. Entomol. 3:233-240.

Hatfield, J.L., K.J. Boote, P. Fay, L. Hahn, C. Izaurralde, B.A. Kimball, T. Mader, J. Morgan, D. Ort, W. Polley, A. Thomson, and D. Wolfe. 2008. Agriculture. In The effects of climate change on agriculture, land resources, water resources, and biodiversity in the United States. U.S. Climate Change Science Program and the Subcommittee on Global Change Res., Washington, DC.

Hatfield, J.L., and J.H. Prueger. 2004. Impact of changing precipitation patterns on water quality. J. Soil Water Conserv. 59:51-58.

Hatfield, J.L., J.H. Prueger, and W.P. Kustas. 2004. Remote sensing of dryland crops. p. 531-568. In S.L. Ustin (ed.) Remote sensing for natural resource management and environmental monitoring. Manual of remote sensing, Vol. 4. 3rd ed. John Wiley, Hoboken, NJ.

Hayhoe, K., C. Wake, T. Huntington, L. Luo, M. Schwartz, J. Sheffield, E. Wood, B. Anderson, J. Bradbury, A. Degaetano, T. Troy, and D. Wolfe. 2007. Past and future changes in climate and hydrological indicators in the U.S. Clim. Dynam. 28:381-407.

Heagle, A.S. 1989. Ozone and crop yield. Annu. Rev. Phytopathol.27:397-423.

Herrero, M.P., and R.R. Johnson. 1980. High temperature stress and pollen viability in maize. Crop Sci. 20:796-800.

Hesketh, J.D., D.L. Myhre, and C.R. Willey. 1973. Temperature control of time intervals between vegetative and reproductive events in soybeans. Crop Sci. 13:250-254.

Hlavinka, P., M. Trnka, D. Semeradova, M. Dubrovsky, Z. Zalud, and M. Mozny. 2009. Effect of drought on yield variability of key crops in Czech republic. Agric. For. Meteorol. 149:431-442.

Hodges, T., and J.T. Ritchie. 1991. The CERES-Wheat phenology model. p. 115-131. In T. Hodges (ed.) Predicting crop phenology. CRC Press, Boca Raton, FL.

Horie, T., J.T. Baker, H. Nakagawa, T. Matsui, and H.Y. Kim. 2000. Crop ecosystem responses to climatic change: Rice. p. 81-106. In K.R. Reddy and H.F. Hodges (ed.) Climate change and global crop productivity. CAB Int., New York.

Hui, D., Y. Luo, W. Cheng, J.S. Coleman, D. Johnson, and D.A. Sims. 2001. Canopy radiation- and water-use efficiencies as affected by elevated $\mathrm{CO}_{2}$. Glob. Change Biol. 7:75-91.

Hunsaker, D.J., G.R. Hendrey, B.A. Kimball, K.F. Lewin, J.R. Mauney, and J. Nagy. 1994. Cotton evapotranspiration under field conditions with $\mathrm{CO}_{2}$ enrichment and variable soil moisture regimes. Agric. For. Meteorol. 70:247-258.

Hunsaker, D.J., B.A. Kimball, P.J. Pinter, Jr., R.L. LaMorte, and G.W. Wall. 1996. Carbon dioxide enrichment and irrigation effects on wheat evapotranspiration and water use efficiency. Trans. ASAE 39:1345-1355.

Hunsaker, D.J., B.A. Kimball, P.J. Pinter, Jr., G.W. Wall, R.L. LaMorte, F.J. Adamsen, S.W. Leavitt, T.W. Thompson, and T.J. Brooks. 2000. $\mathrm{CO}_{2}$ enrichment and soil nitrogen effects on wheat evapotranspiration and water use efficiency. Agric. For. Meteorol. 104:85-100.

Imin, N., T. Kerim, B.G. Rolfe, and J.J. Weinman. 2004. Effect of early cold stress on the maturation of rice anthers. Proteomics 4:1873-1882.

IPCC. 2001. In J.T. Houghton et al. (ed.) Climate change 2001: The scientific basis, contribution from Working Group I to the third assessment report, Inter-governmental Panel for Climate Change. Cambridge Univ. Press, Cambridge, UK.

IPCC. 2007. In R.K. Pachauri and A. Reisinger (ed.) Climate change 2007: Synthesis report. Contribution of Working Groups I, II and III to the fourth assessment report of the Intergovernmental Panel on Climate Change. IPCC, Geneva, Switzerland.

Izaurralde, R.C., N.J. Rosenberg, R.A. Brown, and A.M. Thomson. 2003. Integrated assessment of Hadley Centre climate change projections on water resources and agricultural productivity in the conterminous United States. II. Regional agricultural productivity in 2030 and 2095. Agric. For. Meteorol. 117:97-122.

Jifon, J.L., and D.W. Wolfe. 2005. High temperature-induced sink limitation alters growth and photosynthetic acclimation to elevated $\mathrm{CO}_{2}$ in beans (Phaseolus vulgaris L.). J. Am. Soc. Hortic. Sci. 130:515-520.

Jones, P., J.W. Jones, and L.H. Allen, Jr. 1985. Seasonal carbon and water balances of soybeans grown under stress treatments in sunlit chambers. Trans. ASAE 28:2021-2028.

Jones, R.J., S. Ouattar, and R.K. Crookston. 1984. Thermal environment during endosperm cell division and grain filling in maize: Effects on kernel growth and development in vitro. Crop Sci. 24:133-137.

Kakani, V.G., K.R. Reddy, S. Koti, T.P. Wallace, P.V.V. Prasad, V.R. Reddy, and D. Zhao. 2005. Differences in in vitro pollen germination and pollen tube growth of cotton cultivars in response to high temperature. Ann. Bot. (London) 96:59-67.

Karl, T.R., J.M. Melillo, and T.C. Peterson (ed.). 2009. Global climate change impacts in the United States. Cambridge Univ. Press, New York.

Kim, H.Y., T. Horie, H. Nakagawa, and K. Wada. 1996. Effects of elevated $\mathrm{CO}_{2}$ concentration and high temperature on growth and yield of rice. II. The effect of yield and its component of Akihikari rice. Jpn. J. Crop. Sci. 65:644-651.

Kimball, B.A. 1983. Carbon dioxide and agricultural yield. An assemblage of 430 prior observations. Agron. J. 75:779-788.

Kimball, B.A. 2007. Global change and water resources. p. 627-654. In R.J. Lascano and R.E. Sojka (ed.) Irrigation of agricultural crops. Agron. Monogr. 30.2nd ed. ASA, CSSA, and SSSA, Madison, WI.

Kimball, B.A. 2010. Lessons from FACE: $\mathrm{CO}_{2}$ Effects and interactions with water, nitrogen, and temperature. p. 87-107. In D. Hillel and C. Rosenzweig (ed.) Handbook of climate change and agroecosystems: Impacts, adaptation, and mitigation. Imperial College Press, London UK.

Kimball, B.A., and S.B. Idso. 1983. Increasing atmospheric $\mathrm{CO}_{2}$ : Effects on crop yield, water use, and climate. Agric. Water Manage. 7:55-72.

Kimball, B.A., K. Kobayashi, and M. Bindi. 2002. Responses of agricultural crops to free-air $\mathrm{CO}_{2}$ enrichment. Adv. Agron. 77:293-368.

Kimball, B.A., R.L. LaMorte, P.J. Pinter, Jr., G.W. Wall, D.J. Hunsaker, F.J. Adamsen, S.W. Leavitt, T.L. Thompson, A.D. Matthias, and T.J. Brooks. 1999. Free-air $\mathrm{CO}_{2}$ enrichment (FACE) and soil nitrogen effects on energy balance and evapotranspiration of wheat. Water Resour. Res. 35:1179-1190.

Kimball, B.A., and J.R. Mauney. 1993. Response of cotton to varying $\mathrm{CO}_{2}$, irrigation, and nitrogen: Yield and growth. Agron. J. 85:706-712.

Kimball, B.A., C.F. Morris, P.J. Pinter, Jr., G.W. Wall, D.J. Hunsaker, F.J. Adamsen, R.L. LaMorte, S.W. Leavitt, T.L. Thompson, A.D. Matthias, and T.J. Brooks. 2001. Elevated $\mathrm{CO}_{2}$, drought and soil nitrogen effects on wheat grain quality. New Phytol. 150:295-303.

Kimball, B.A., P.J. Pinter, R.L. Garcia, R.L. LaMorte, G.W. Wall, D.J. Hunsaker, G. Wechsung, F. Wechsung, and T. Kartschall. 1995. Productivity and water use of wheat under free-air $\mathrm{CO}_{2}$ enrichment. Glob. Change Biol. 1:429-442.

King, K.M., and D.H. Greer. 1986. Effects of carbon dioxide enrichment and soil water on maize. Agron. J. 78:515-521.

Kiniry, J.R., and R. Bonhomme. 1991. Predicting maize phenology. p. 115-131. In T. Hodges (ed.) Predicting crop phenology. CRC Press, Boca Raton, FL.

Ko, J., L. Ahuja, B. Kimball, S. Anapalli, L. Ma, T.R. Green, A.C. Ruane, G.W. Wall, P. Pinter, and D.A. Bader. 2010. Simulation of free air $\mathrm{CO}_{2}$ enriched wheat growth and interactions with water, nitrogen, and temperature. Agric. For. Meteorol. 150:1331-1346.

Kobza, J., and G.E. Edwards. 1987. Influences of leaf temperature on photosynthetic carbon metabolism in wheat. Plant Physiol. 83:69-74.

Kucharik, C.J., and S.P. Serbin. 2008. Impacts of recent climate change on Wisconsin corn and soybean yield trends. Environ. Res. Lett. 3:1-10. 
Laing, D.R., P.G. Jones, and J.H. Davis. 1984. Common bean (Phaseolus vulgaris L.). p. 305-351. In P.R. Goldsworthy and N.M. Fisher (ed.) The physiology of tropical field crops. John Wiley \& Sons, New York.

Laux, P., G. Jackel, R.M. Tingem, and H. Kunstmann. 2010. Impact of climate change on agricultural productivity under rainfed conditions in Cameroon-A method to improved attainable crop yields by planting date adaptations. Agric. For. Meteorol. 150:1258-1271.

Lawlor, D.W., and R.A.C. Mitchell. 2000. Crop ecosystem responses to climatic change: Wheat. p. 57-80. In K.R. Reddy, and H.F. Hodges (ed.) Climate change and global crop productivity. CAB Int., New York.

Lawson, T., J. Craigon, C.R. Black, J.J. Colls, G. Landon, and J.D.B. Weyers. 2002. Impact of elevated $\mathrm{CO}_{2}$ and $\mathrm{O}_{3}$ on gas exchange parameters and epidermal characteristics in potato (Solanum tuberosum L.) 53:737-746.

Leakey, A.D.B., M. Uribelarrea, E.A. Ainsworth, S.L. Naidu, A. Rogers, D.R. Ort, and S.P. Long. 2006. Photosynthesis, productivity, and yield of maize are not affected by open-air elevation of $\mathrm{CO}_{2}$ concentration in the absence of drought. Plant Physiol. 140:779-790.

Lejeune, K.R., J.L. Griffin, D.B. Reynolds, and A.M. Saxton. 1994. Itchgrass (Rottboellia cochinchinensis) interference in soybean (Glycine max). Weed Technol. 8:733-737.

Lencse, R.J., and J.L. Griffin. 1991. Itchgrass (Rottboellia cochinchinensis) interference in sugarcane (Saccharum sp.). Weed Technol. 5:396-399.

Lettenmaier, D.P., D. Major, L. Poff, and S. Running. 2008. Water resources. p. 362. In The effects of climate change on agriculture, land resources, water resources, and biodiversity in the United States. U.S. Climate Change Science Program and the Subcommittee on Global Change Res., Washington, DC.

Lobell, D.B. 2007. Changes in diurnal temperature and national cereal yields. Agric. For. Meteorol. 145:229-238.

Lobell, D.B., and C.B. Field. 2007. Global scale climate-crop yield relationships and the impact of recent warming. Environ. Res. Lett. 2:1-7.

Long, S.P. 1991. Modification of the response of photosynthetic productivity to rising temperature by atmospheric $\mathrm{CO}_{2}$ concentrations: Has it importance been underestimated? Plant Cell Environ. 14:729-739.

Long, S.P., E.A. Ainsworth, A.D.B. Leakey, J. Nosberger, and D.R. Ort. 2006. Food for thought: Lower-than-expected crop yield stimulation with rising $\mathrm{CO}_{2}$ concentrations. Science (Washington, DC) 213:1918-1921.

Magliulo, V., M. Bindi, and G. Rana. 2003. Water use of irrigated potato (Solanum tuberosum L.) grown under free air carbon dioxide enrichment in central Italy. Agric. Ecosys. Environ. 97:65-80.

Maiti, R.K. 1996. Sorghum science. Science Publ., Lebanon, NH.

Malcolm,J.R.,A. Markham, R.P.Neilson, and M. Garaci. 2002.Estimated migration rates under scenarios of global climate change. J. Biogeography 29:835-849.

Maroco, J.P., G.E. Edwards, and M.S.B. Ku. 1999. Photosynthetic acclimation of maize to growth under elevated levels of carbon dioxide. Planta 210:115-125.

Matsui, T., O.S. Namuco, L.H. Ziska, and T. Horie. 1997. Effects of high temperature and $\mathrm{CO}_{2}$ concentration on spikelet sterility in indica rice. Field Crops Res. 51:213-219.

Matsushima, S., T. Tanaka, and T. Hoshino. 1964. Analysis of yield determining process and its application to yield-prediction and culture improvement of lowland rice. LXX. Combined effect of air temperature and water temperature at different stages of growth on the grain yield and its components of lowland rice. Proc. Crop Sci. Soc. Jpn. 33:53-58.

Medlyn, B.E., C.V.M. Barton, M.S.J. Broadmeadow, R. Ceulemans, P. De Angelis, M. Forstreuter, M. Freeman, S.B. Jackson, S. Kellomaki, E. Laitat, A. Rey, P. Roberntz, B.D. Sigurdsson, J. Strassemeyer, K. Wang, P.S. Curtis, and P.G. Jarvis. 2001. Stomatal conductance of forest species after long-term exposure to elevated $\mathrm{CO}_{2}$ concentration: A synthesis. New Phytol. 149:247-264.

Miller, J.E., A.S. Heagle, and W.A. Pursley. 1998. Influence of ozone stress on soybean response to carbon dioxide enrichment: II. Biomass and development. Crop Sci. 38:122-128.

Mills, G., G. Ball, F. Hayes, J. Fuhrer, L. Skarby, B. Gimeno, L. De Temmerman, and A. Heagle. 2000. Development of a multi-factor model for predicting the effects of ambient ozone on the biomass of white clover. Environ. Pollut. 109:533-542.

Mishra, V., and K.A. Cherkauer. 2010. Retrospective droughts in the crop growing season: Implications to corn and soybean yield in the Midwestern United States. Agric. For. Meteorol. 150:1030-1045.

Montaigne, F. 2004. The heat is on: Eco-signs. Natl. Geographic 206:34-55.

Morgan, P.B., E.A. Ainsworth, and S.P. Long. 2003. How does elevated ozone impact soybean? A meta-analysis of photosynthesis, growth and yield. Plant Cell Environ. 26:1317-1328.
Morgan, P.B., C.J. Bernacchi, D.R. Ort, and S.P. Long. 2004. An in vivo analysis of the effect of season-long open-air elevation of ozone to anticipated 2050 levels on photosynthesis in soybean. Plant Physiol. 135:2348-2357.

Morgan, P.B., T.A. Mies, G.A. Bollero, R.L. Nelson, and S.P. Long. 2006. Season-long elevation of ozone concentration to projected 2050 levels under fully open-air conditions substantially decreases the growth and production of soybean. New Phytol. 170:333-343.

Morison, J.I.L. 1987. Intercellular $\mathrm{CO}_{2}$ concentration and stomatal response to $\mathrm{CO}_{2}$. p. 229-251. In E. Zeiger et al. (ed.) Stomatal function. Stanford Univ. Press, Stanford, CA.

Muchow, R.C., T.R. Sinclair, and J.M. Bennett. 1990. Temperature and solar-radiation effects on potential maize yield across locations. Agron. J. 82:338-343.

Noormets, A., A. Sôber, E.J. Pell, R.E. Dickson, G.K. Podila, J. Sôber, J.G. Isebrands, and D.F. Karnosky. 2001. Stomatal and non-stomatal limitation to photosynthesis in two trembling aspen (Populus tremuloides Michx.) clones exposed to elevated $\mathrm{CO}_{2}$ and/or $\mathrm{O}_{3}$. Plant Cell Environ. 24:327-336.

Oberhuber, W., and G.E. Edwards. 1993. Temperature dependence of the linkage of quantum yield of photosystem II to $\mathrm{CO}_{2}$ fixation in $\mathrm{C}_{4}$ and $\mathrm{C}_{3}$ plants. Plant Physiol. 101:507-512.

Ong, C.K. 1986. Agroclimatological factors affecting phenology of groundnut. In Agrometeorology of Groundnut. Proc. of an Int. Symp. 21-26 Aug. 1985. ICRISAT Sahelian Center, Niamey, Niger. ICRISAT, Patancheru, India.

Ortiz, R., K.D. Sayre, B. Govaerts, R. Gupta, G.V. Subbarao, T. Ba, D. Hodson, J.M. Dixon, J.I. Ortiz-Monasterio, and M. Reynolds. 2008. Climate change: Can wheat beat the heat? Agric. Ecosyst. Environ. 126:46-58.

Ottman, M.J., B.A. Kimball, P.J. Pinter, G.W. Wall, R.L. Vanderlip, S.W. Leavitt, R.L.LaMorte, A.D. Matthias, and T.J. Brooks. 2001. Elevated $\mathrm{CO}_{2}$ increases sorghum biomass under drought conditions. New Phytol. 15:261-273.

Pan, D. 1996. Soybean responses to elevated temperature and doubled $\mathrm{CO}_{2}$ Ph.D. diss. Univ. of Florida, Gainesville.

Patterson, D.T. 1993. Implications of global climate change for impact of weeds, insects and plant diseases. Int. Crop Sci. 1:273-280.

Patterson, D.T. 1995a. Weeds in a changing climate. Weed Sci. 43:685-701.

Patterson, D.T. 1995b. Effects of environmental stress on weed/crop interactions. Weed Sci. 43:483-490.

Patterson, D.T., C.R. Meyer, E.P. Flint, and P.C. Quimby, Jr. 1979. Temperature responses and potential distribution of itchgrass (Rottboellia exaltata) in the United States. Weed Sci. 27:77-82.

Patterson, D.T., J.K. Westbrook, R.J.C. Joyce, P.D. Lingren, and J. Rogasik. 1999. Weeds, insects and diseases. Clim. Change 43:711-727.

Paulsen, G.M. 1994. High temperature responses of crop plants. p. 365-389. In K.J. Boote et al. (ed.) Physiology and determination of crop yield. ASA, CSSA, and SSSA, Madison, WI.

Peng, S., J. Huang, J.E. Sheehy, R.C. Lanza, R.M. Visperas, X. Zhong, G.S. Centeno, G.S. Khush, and K.G. Cassman. 2004. Rice yields decline with higher night temperature from global warming. Proc. Natl. Academy Sci. 101:9971-9975.

Pettigrew, W.T. 2008. The effect of higher temperature on cotton lint yield production and fiber quality. Crop Sci. 48:278-285.

Pickering, N.B., J.W. Jones, and K.J. Boote. 1995. Adapting SOYGRO V5.42 for prediction under climate change conditions. p. 77-98. In C. Rosenzweig et al. (ed.) Climate change and Agriculture: Analysis of potential international impacts. ASA Spec. Publ. 59. ASA, CSSA, and SSSA, Madison, WI.

Piper, E.L., K.J. Boote, and J.W. Jones. 1998. Evaluation and improvement of crop models using regional cultivar trial data. Appl. Eng. Agric. 14:435-446.

Prasad, P.V.V., K.J. Boote, and L.H. Allen, Jr. 2006a. Adverse high temperature effects on pollen viability, seed-set, seed yield and harvest index of grainsorghum Sorghum bicolor (L.) Moench are more severe at elevated carbon dioxide due to high tissue temperature. Agric. For. Meteorol. 139:237-251.

Prasad, P.V.V., K.J. Boote, L.H. Allen, Jr., J.E. Sheehy, and J.M.G. Thomas. 2006 b. Species, ecotype and cultivar differences in spikelet fertility and harvest index of rice in response to high temperature stress. Field Crops Res. 95:398-411.

Prasad, P.V.V., K.J. Boote, L.H. Allen, Jr., and J.M.G. Thomas. 2002. Effects of elevated temperature and carbon dioxide on seed-set and yield of kidney bean (Phaseolus vulgaris L.). Glob. Change Biol. 8:710-721.

Prasad, P.V.V., K.J. Boote, L.H. Allen, Jr., and J.M.G. Thomas. 2003. Supraoptimal temperatures are detrimental to peanut (Arachis hypogaea $\mathrm{L}$ ) reproductive processes and yield at ambient and elevated carbon dioxide. Glob. Change Biol. 9:1775-1787.

Prasad, P.V.V., P.Q. Craufurd, V.G. Kakani, T.R. Wheeler, and K.J. Boote. 2001. Influence of high temperature during pre- and postanthesis stages of floral development on fruit-set and pollen germination in peanut. Aust. J. Plant Physiol. 28:233-240. 
Prasad, P.V.V., S.R. Pisipati, Z. Ristic, U. Bukovnik, and A.K. Fritz. 2008. Effect of nighttime temperature on physiology and growth of spring wheat. Crop Sci. 48:2372-2380.

Pushpalatha, P., P. Sharma-natu, and M.C. Ghildiyal. 2008. Photosynthetic response of wheat cultivar to long-term exposure to elevated temperature. Photosynthetica 46:552-556.

Reddy, K.R., G.H. Davidonis, A.S. Johnson, and B.T. Vinyard. 1999. Temperature regime and carbon dioxide enrichment alter cotton boll development and fiber properties. Agron. J. 91:851-858.

Reddy, K.R., H.F. Hodges, and B.A. Kimball. 2000. Crop ecosystem responses to climatic change: Cotton. p. 161-187. In K.R. Reddy and H. F. Hodges (ed.) Climate change and global crop productivity. CAB Int., New York.

Reddy, K.R., H.F. Hodges, and J.M. McKinion. 1995a. Carbon dioxide and temperature effects on Pima cotton growth. Agric. Ecosyst. Environ. 54:17-29.

Reddy, K.R., H.F. Hodges, and J.M. McKinion. 1997. A comparison of scenarios for the effect of global climate change on cotton growth and yield. Aust. J. Plant Physiol. 24:707-713.

Reddy, K.R., H.F. Hodges, J.M. McKinion, and G.W. Wall. 1992a. Temperature effects on Pima cotton growth and development. Agron. J. 84:237-243.

Reddy, K.R., H.F. Hodges, and V.R. Reddy. 1992b. Temperature effects on cotton fruit retention. Agron. J. 84:26-30.

Reddy, K.R., P.V. Vara Prasad, and V.G. Kakani. 2005. Crop responses to elevated carbon dioxide and interactions with temperature: Cotton. J. Crop Improv. 13:157-191.

Reddy, V.R., D.N. Baker, and H.F. Hodges. 1991. Temperature effects on cotton canopy growth, photosynthesis, and respiration. Agron. J. 83:699-704.

Reddy, V.R., K.R. Reddy, and H.F. Hodges. 1995b. Carbon dioxide enrichment and temperature effects on cotton canopy photosynthesis, transpiration, and water use efficiency. Field Crops Res. 41:13-23.

Rejmanek, M. 1996. A theory of seed plant invasiveness: The first sketch. Biol. Conserv. 78:171-181.

Ritchie, J.T. 1972. Model for predicting evaporation from a row crop with incomplete cover. Water Resour. Res. 8:1204-1213.

Rosenzweig, C., F.N. Tubiello, R. Goldberg, E. Mills, and J. Bloomfield. 2002. Increased crop damage in the US from excess precipitation under climate change. Glob. Environ. Change 12:197-202.

Rudorff, B.F.T., C.L. Mulchi, C.S.T. Daughtry, and E.H. Lee. 1996. Growth, radiation use efficiency, and canopy reflectance of wheat and corn grown under elevated ozone and carbon dioxide atmospheres. Remote Sens. Environ. 55:163-173.

Runge, E.C.A. 1968. Effect of rainfall and temperature interactions during the growing season on corn yield. Agron. J. 60:503-507.

Salem, M.A., V.G. Kakani, S. Koti, and K.R. Reddy. 2007. Pollen-based screening of soybean genotypes for high temperature. Crop Sci. 47:219-231.

Sasek, T.W., and B.R. Strain. 1990. Implications of atmospheric $\mathrm{CO}_{2}$ enrichment and climatic change for the geographical distribution of two introduced vines in the USA. Clim. Change 16:31-51.

Satake, T., and S. Yoshida. 1978. High temperature-induced sterility in indica rice at flowering. Jpn. J. Crop. Sci. 47:6-17.

Sau, F., K.J. Boote, W.M. Bostick, J.W. Jones, and M.I. Minguez. 2004. Testing and improving evapotranspiration and soil water balance of the DSSAT crop models. Agron. J. 96:1243-1257.

Sayfa, P., A. Saha, and N.K. Singh. 2010. Screening for low temperature tolerance in boro rice. Int. Rice Res. Notes 35:1-4.

Schlenker, W., and M.J. Roberts. 2009. Nonlinear temperature effects indicate severe damages to U.S. crop yields under climate change. Proc. Natl. Acad. Sci. USA 106:15594-15598.

Schoper, J.B., R.J. Lambert, B.L. Vasilas, and M.E. Westgate. 1987. Plant factors controlling seed set in maize. Plant Physiol. 83:121-125.

Schwartz, M.D., R. Ahas, and A. Aasa. 2006. Onset of spring starting earlier across the Northern Hemisphere. Glob. Change Biol. 12:343-351.

Sexton, P.J., J.W. White, and K.J. Boote. 1994. Yield-determining processes in relation to cultivar seed size of common bean. Crop Sci. 34:84-91.

Snyder, A.M. 2000. The effects of elevated carbon dioxide and temperature on two cultivars of rice. M.S. thesis. Univ. of Florida, Gainesville.

Sofield, I., L.T. Evans, M.G. Cook, and I.F. Wardlaw. 1977. Factors influencing the rate and duration of grain filling in wheat. Aust. J. Plant Physiol. 4:785-797.

Sofield, I., L.T. Evans, and I.F. Wardlaw. 1974. The effects of temperature and light on grain filling in wheat. p. 909-915. In R.L. Bieleski et al. (ed.) Mechanisms of regulation of plant growth. Bull. 12. R. Soc. New Zealand, Wellington.

Stanhill, G., and S. Cohen. 2001. Global dimming: A review of the evidence for a widespread and significant reduction in global radiation with dis- cussion of its probable causes and possible agricultural consequences. Agric. For. Meteorol. 107:255-278.

Stivers, L. 1999. Crop profiles for corn (sweet) in New York. Available at http://www.ipmcenters.org/cropprofiles/docs/nycorn-sweet.pdf (verified 15 Dec. 2010). NSF Ctr. for Integrated Pest Manage., North Carolina State Univ., Raleigh.

Stockle, C.O., P.T. Dyke, J.R. Williams, C.A. Jones, and N.J. Rosenberg. 1992a. A method for estimating the direct and climatic effects of rising atmospheric carbon dioxide on growth and yield of crops: Part II-Sensitivity analysis at three sites in the Midwestern USA. Agric. Syst. 38:239-256.

Stockle, C.O., J.R. Williams, N.J. Rosenberg, and C.A. Jones. 1992b. A method for estimating the direct and climatic effects of rising atmospheric carbon dioxide on growth and yield of crops: Part 1-Modification of the EPIC model for climate change analysis. Agric. Syst. 38:225-238.

Tashiro, T., and I.F. Wardlaw. 1990. The response to high temperature shock and humidity changes prior to and during the early stages of grain development in wheat. Aust. J. Plant Physiol. 17:551-561.

Tebaldi, C., K. Hayhoe, J.M. Arblaster, and G.E. Meehl. 2006. Climate change, Going to the extremes, An intercomparison of model simulated historical and future changes in extreme events. Clim. Change 79:185-211.

Temple, P.J. 1990. Growth form and yield responses of 4 cotton cultivars to ozone. Agron. J. 82:1045-1050.

Thomas, J.M.G. 2001. Impact of elevated temperature and carbon dioxide on development and composition of soybean seed. Ph.D. diss. Univ. of Florida, Gainesville.

Tingey, D.T., K.D. Rodecap, E.H. Lee, W.E. Hogsett, and J.W. Gregg. 2002. Pod development increases the ozone sensitivity of Phaseolus vulgaris. Water Air Soil Pollut. 139:325-341.

Tommasi, P.D., V. Magliulo, R. Dell'Aquila, F. Miglietta, A. Zaldei, and G. Gaylor. 2002. Water consumption of a $\mathrm{CO}_{2}$ enriched poplar stand. Atti del Convegno, CNR-ISAFOM, Ercolano, Italy.

Treharne, K. 1989. The implications of the 'greenhouse effect' for fertilizers and agrochemicals. p. 67-78. In R.D. Bennet (ed.) The greenhouse effect and UK agriculture. Ministry of Agriculture, Fisheries and Food, London.

Triggs, J.M., B.A. Kimball, P.J. Pinter, Jr., G.W. Wall, M.M. Conley, T.J. Brooks, R.L. LaMorte, N.R. Adam, M.J. Ottman, A.D. Matthias, S.W. Leavitt, and R.S. Cerveny. 2004. Free-air carbon dioxide enrichment (FACE) effects on energy balance and evapotranspiration of sorghum. Agric. For. Meteorol. 124:63-79.

Van Dingenen, R., F.J. Dentener, F. Raes, M.C. Krol, L. Emberson, and J. Cogala. 2008. The global impact of ozone on agricultural crop yields under current and future air. Atmos. Environ. 43:604-618.

Villalobos, F.J., and E. Fereres. 1990. Evaporation measurements beneath corn, cotton, and sunflower canopies. Agron. J. 82:1153-1159.

Wall, G.W., T.J. Brooks, R. Adam, A.B. Cousins, B.A. Kimball, P.J. Pinter, R.L. LaMorte, L. Trigs, M.J. Ottman, S.W. Leavitt, A.D. Matthias, D.G. Williams, and A.N. Webber. 2001. Elevated atmospheric $\mathrm{CO}_{2}$ improved sorghum plant water status by ameliorating the adverse effects of drought. New Phytol. 152:231-248.

Wall, G.W., R.L. Garcia, B.A. Kimball, D.J. Hunsaker, P.J. Pinter, Jr., S.P. Long, C.P. Osborne, D.L. Hendrix, F. Wechsung, G. Wechsung, S.W. Leavitt, R.L. LaMorte, and S.B. Idso. 2006. Interactive effects of elevated carbon dioxide and drought on wheat. Agron. J. 98:354-381.

Walther, G.R. 2002. Ecological responses to recent climate change. Nature (London) 416:389-395.

Wand, S.J.E., G.F. Midgley, M.H. Jones, and P.S. Curtis. 1999. Responses of wild C4 and $\mathrm{C} 3$ grasses (Poaceae) species to elevated atmospheric $\mathrm{CO}_{2}$ concentration: A meta-analytic test of current theories and perceptions. Glob. Change Biol. 5:723-741.

Wang, G. 2005. Agricultural drought in a future climate: Results from 15 gobal claimte models participating in the IPCC 4th assessment. Clim. Dyn. 25:739-753.

Wang, X., and D.L. Mauzerall. 2004. Characterizing distributions of surface ozone and its impact on grain production in China, Japan, and South Korea:1990 and 2020. Atmos. Environ. 38:4383-4402.

Wassmann, R., S.V.K. Jagadish, S. Heuer, A. Ismail, E. Redona, R. Serraj, R.K. Singh, G. Howell, H. Pathak, and K. Sumfleth. 2009. Climate change affecting rice production: The physiological and agronomic basis for possible adaptation strategies. Adv. Agron. 101:59-122.

Welch, J.A., J.R. Vincent, M. Auffhammer, P.F. Moya, A. Dobermann, and D. Dawe. 2010. Rice yields in tropical/subtropical Asia exhibit large but opposing sensitivities to minimum and maximum temperatures. Proc. Natl. Acad. Sci. USA 107:14562-14567. 
Wheeler, T.R., P.Q. Craufurd, R.H. Ellis, J.R. Porter, and P.V. Vara Prasad. 2000. Temperature variability and the yield of annual crops. Agric. Ecosyst. Environ. 82:159-167.

Whalen, J., M. VanGessel, B. Mulrooney, K. Everts, and S. King. 2007. Crop profile for corn (sweet) in Delaware. Available at http://www.ipmcenters.org/cropprofiles/docs/DEsweetcorn.pdf (verified 15 Dec. 2010). Univ. of Delaware, Newark.

Williams, J.R. 1995. The EPIC model. p. 909-1000. In V.P. Singh (ed.) Computer models of watershed hydrology. Water Resources Publ., Highlands Ranch, CO.

Williams, J.H., J.H.H. Wilson, and G.C. Bate. 1975. The growth of groundnuts (Arachis hypogaea L. cv. Makulu Red) at three altitudes in Rhodesia. Rhodesian J. Agric. Res. 13:33-43.

Wolfe, D.W. 1994. Physiological and growth responses to atmospheric $\mathrm{CO}_{2}$ concentration. In M. Pessarakli (ed.) Handbook of plant and crop physiology. Marcel Dekker, New York.

Wolfe, D.W., L. Ziska, C. Petzoldt, A. Seaman, L. Chase, and K. Hayhoe. 2008. Projected change in climate thresholds in the Northeastern U.S.: Implications for crops, pests, livestock, and farmers. Mitig. Adapt. Strategies Glob. Change 13:555-575.

Wolfe, D.W., R. Gifford, D. Hilbert, and Y. Luo. 1998. Integration of acclimation to elevated $\mathrm{CO}_{2}$ at the whole-plant level. Glob. Change Biol. 4:879-893.

Wolfe, D.W., M.D. Schwartz, A.N. Lakso, Y. Otsuki, R.M. Pool, and N. Shaulis. 2005. Climate change and shifts in spring phenology of three horticultural woody perennials in northeastern USA. Int. J. Biometeorol. 49:303-309.

Wullschleger, S.D., and R.J. Norby. 2001. Sap velocity and canopy transpiration in a sweetgum stand exposed to free-air $\mathrm{CO}_{2}$ enrichment (FACE). New Phytol. 150:489-498.
Xiao, T.G., Q.Zhang, Y. Yao, H.Zhao, R. Wang, H. Bai, and F.Zhang. 2008. Impact of recent climatic change on the yield of winter wheat at low and high altitudesin semi-arid northwestern China. Agric. Ecosyst. Environ. 127:37-42.

Yoshimoto, M., H. Oue, and K. Kobayashi. 2005. Responses of energy balance, evapotranspiration, and water use efficiency of canopies to free-air $\mathrm{CO}_{2}$ enrichment. Agric. For. Meteorol. 133:226-246.

Ziska, L.H. 2000. The impact of elevated $\mathrm{CO}_{2}$ on yield loss from a $\mathrm{C}_{3}$ and $\mathrm{C}_{4}$ weed in field-grown soybean. Glob. Change Biol. 6:899-905.

Ziska, L.H. 2003a. Evaluation of yield loss in field sorghum from a $\mathrm{C}_{3}$ and $\mathrm{C}_{4}$ weed with increasing $\mathrm{CO}_{2}$. Weed Sci. 51:914-918.

Ziska, L.H. 2003b. Evaluation of the growth response of six invasive species to past, present and future carbon dioxide concentrations. J. Exp. Bot. 54:395-404.

Ziska, L.H. 2004. Rising carbon dioxide and weed ecology. p. 159-176. In Inderjit (ed.) Weed biology and management. Kluwer Academic Publ., the Netherlands.

Ziska, L.H., and J.A. Bunce. 1997. Influence of increasing carbon dioxide concentration on the photosynthetic and growth stimulation of selected C4 crops and weeds. Photosynth. Res. 54:199-208.

Ziska, L.H., and A. McClung. 2008. Differential response of cultivated and weedy (red) rice to recent and projected increases in atmospheric carbon dioxide. Agron. J. 100:1259-1263.

Ziska, L.H., J.B. Reeves, and B. Blank. 2005. The impact of recent increases in atmospheric $\mathrm{CO}_{2}$ on biomass production and vegetative retention of cheatgrass (Bromus tectorum): Implications for fire disturbance. Glob. Change Biol. 11:1325-1332.

Ziska, L.H., and G.B. Runion. 2007. Future weed, pest and disease problems for plants. p. 262-279. In P.C.D. Newton et al. (ed.) Agroecosystems in a changing climate. CRC Press, Boston, MA.

Ziska, L.H., J.R. Teasdale, and J.A. Bunce. 1999. Future atmospheric carbon dioxide may increase tolerance to glyphosate. Weed Sci. 47:608-615. 